\title{
أبنيّة الأفعال المستدركة على سيبـويّه عند ابن سيده
}

أ. د. مجيب فير الله الزاملي/ كايّة التربيّة / جامعة واسط

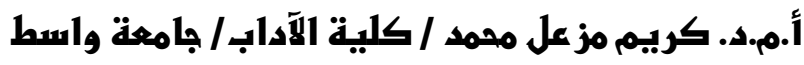

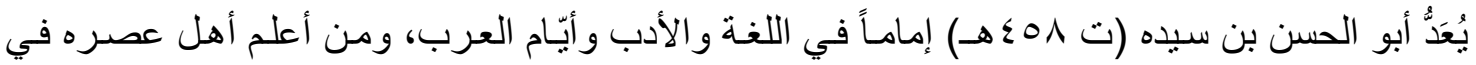

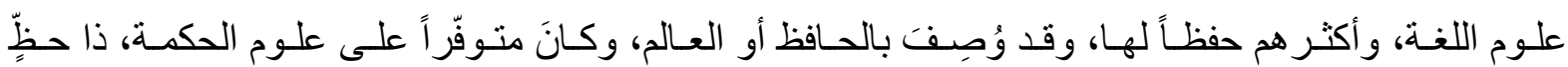

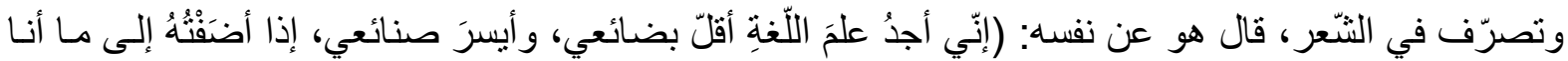
باه من علم حقيق النّحو، وحُوشيّ العروض، وخفيّ القافية، وتصوير الأشكال المنطقيّة، والنّظر في سـائر العلوم

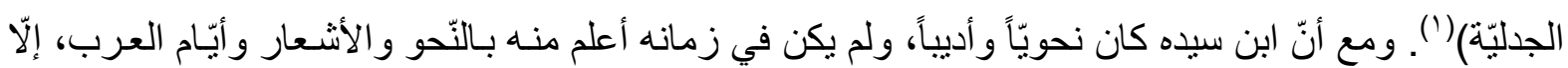
أنّهُ غلبَ عليه علم اللغة وشهرته به بين النّاس، وكان لكتابيه المحكم و المخصص أثر واضح في تحقيق مكانته

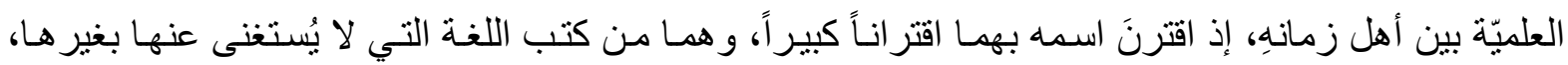

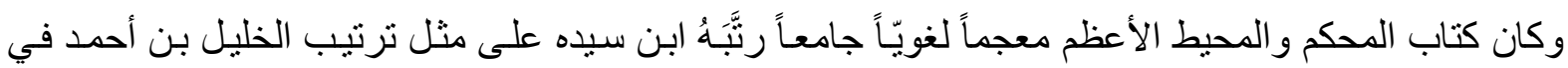
معجم العين، وهو التَّرتيب الذي يتبع مخارج الأصوات، فضمَّ مـادّة لغويّة لا يمكن أن يستغني عنها الباحث في

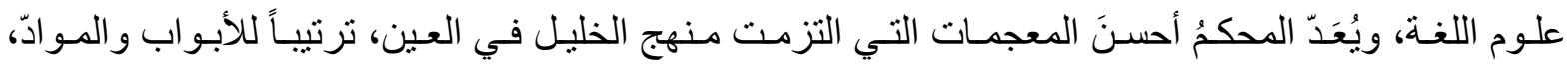

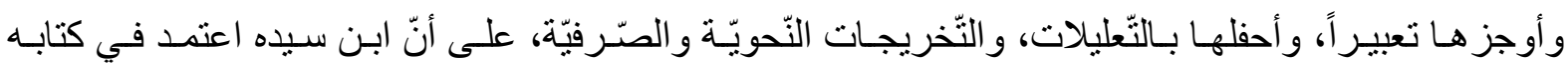
المخصص ترتيباً جديداً لـم يسبقه إلـى مثلـه غيرُهُ، إذ جمع فيـه اللغـة على أسـاس الموضـوعات، وقد كانت

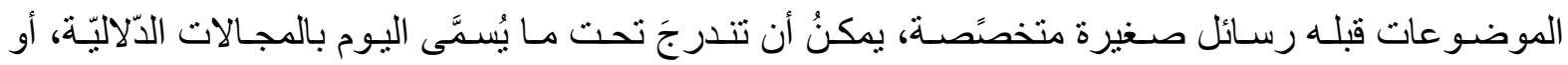

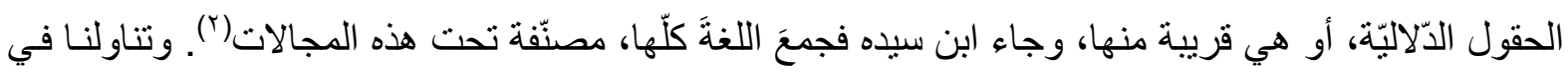

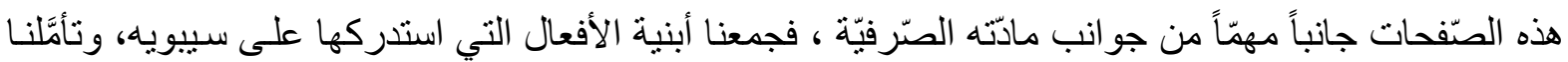
تلك الأبنية، وأوضَحنا مدى أهيّة إثبات أبنية جديدة لم ترد في كلام العرب، إذ أنتار ابن سبده في بعض منها صر احةً إلى أنّ هذه الأبنيـة من فو ائت الكتاب، وترك بعضـها من دون الإشـارة إلى ذلك ، و هذا الجانب من

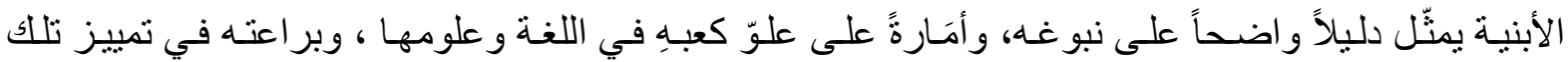

\section{أبنيّة الأفعال المستدركة على سيبـويهّ عند ابن سيده}

جمـع كتاب سييويه بين دفتيه أصسول أكثر من علم من علوم اللغـة العربيـة ، فكان فيـه فضـلاً عن النحو

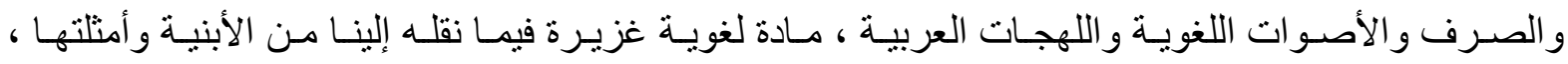
و المفردات و أنو اعها مما وضعه تحت عنوان (هذا بـابُ مـا بنتِ العربُ من الأسماء و الصّّفات والأفعال غير

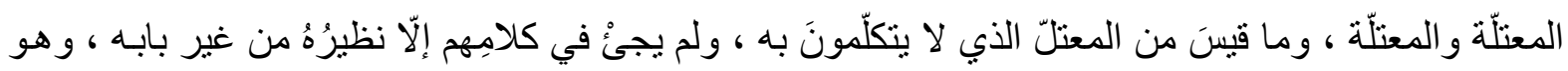
الذي يسمّيه النَّحويون التَّصريف والفعل)("). و هو في هذا البـاب من اللغـة يحاول أن يحيط بأبنيـة الكلام في

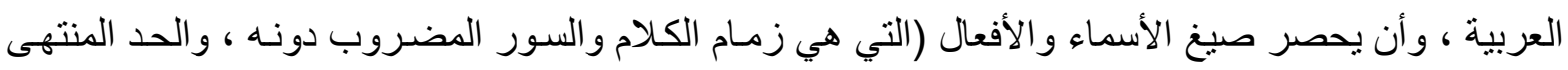


بهه إليه)(")، لذلك يقول بعد أن يعدّد بعض الأبنية (وليس في الكلام أُفِعِل، ولا أَفَعَوْ، ولا أُفعال، و لا أَفْعِيل ،

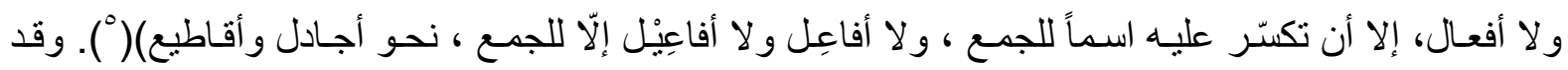

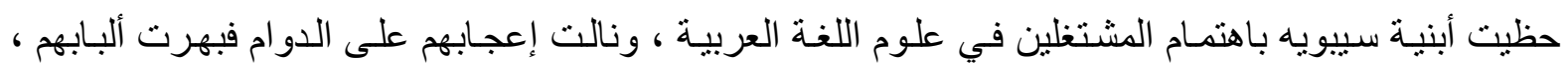
وجذبت أقلامهم ، وجعلتهم يجتهدون في تفسير معانيها ، ويتنافسون في شرح أمثلتها التي استعصت عليهم في

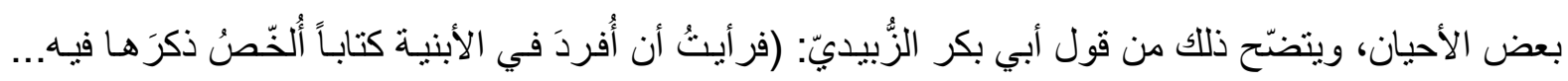
ونشرح بعد كل باب منها ما وقعَ فيهه من غريب الأبنيـة شرحاً كافياً مختصر اً، و إن كان أهلُ اللغة قد تحاموا شرحها ، وتفادوا من تفسير غريبها ، وشهدوا لسيبويه بالتقدّم في علم اللغة بما أثنته في كتابه منها، حين أيقنوا ونئه

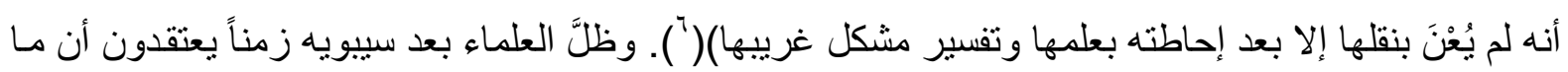

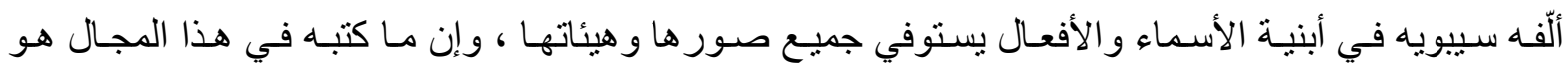

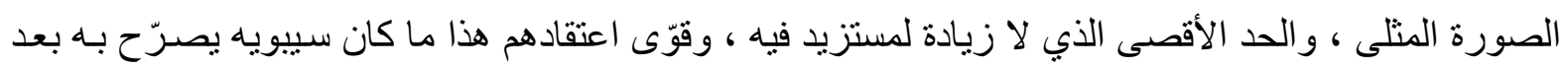

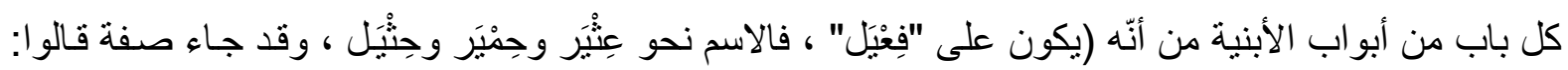

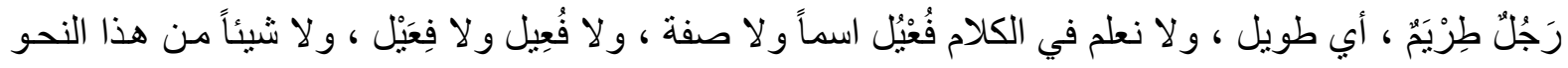

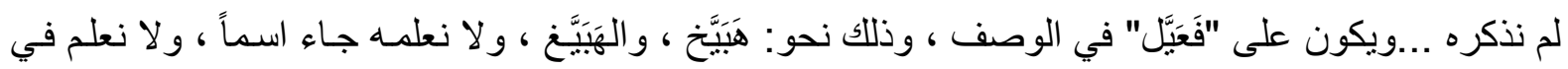

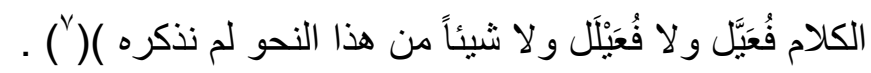

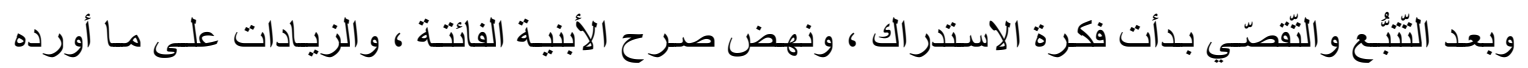
سيبويه منها ، وشرع العلماء في البحث والتّقيب في طلب الصيخ وأمثلتها، يقول الزُّبيديّ: (وكان جلّةُة المشايخ من أهل النحو فيما روينا عنهم يزعمون أن ما ألّفه سيبويه منها يستوفي جميعَ أبنية الكلام ، مـا خـلا ثلاثنة أبنية

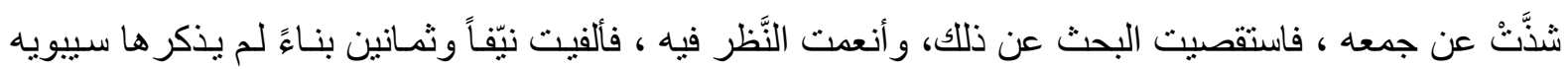

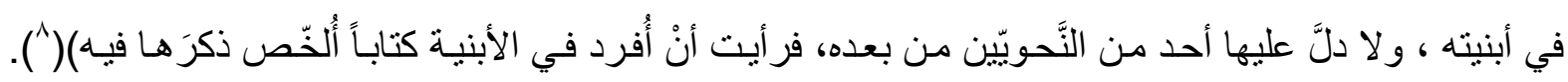

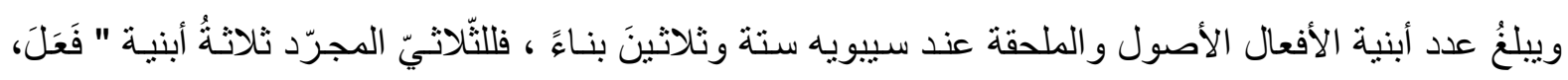

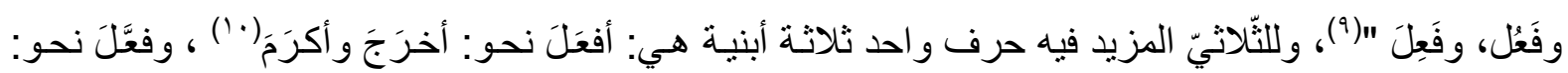

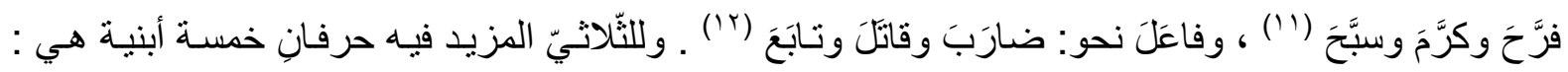

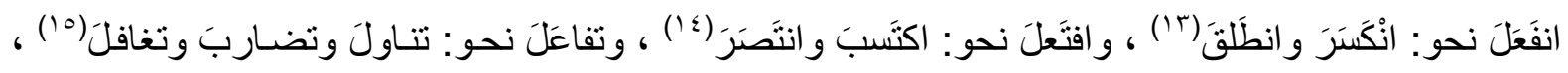

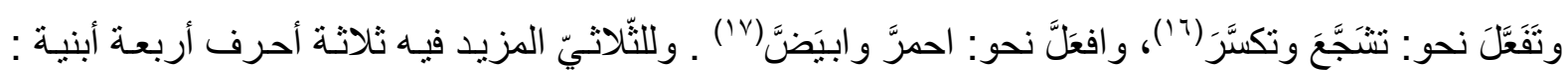

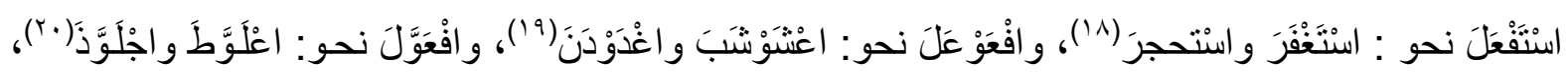

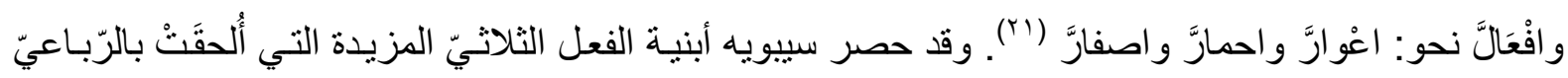

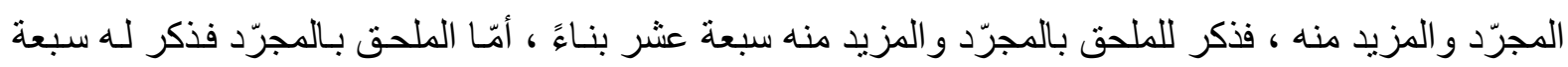

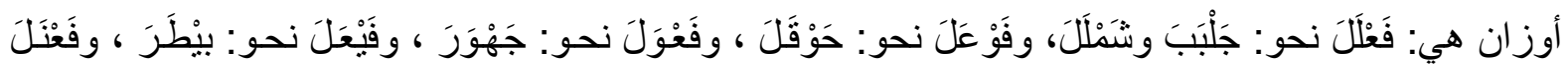

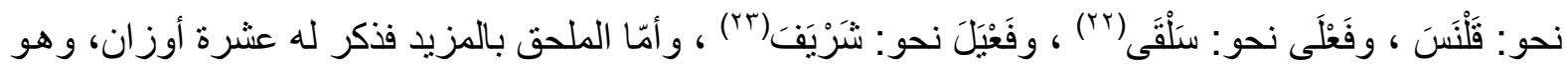

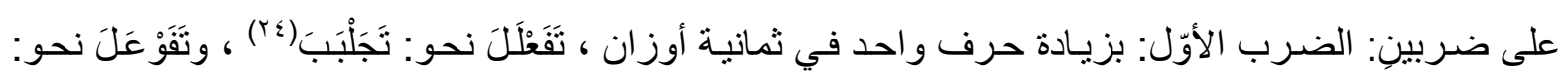

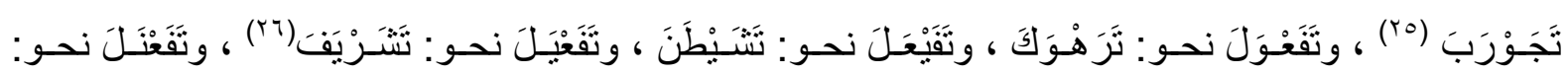




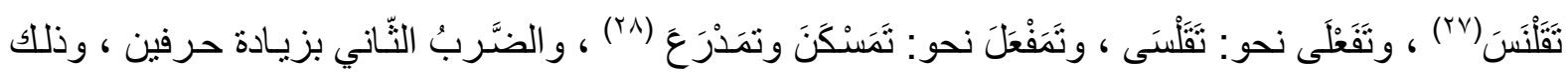

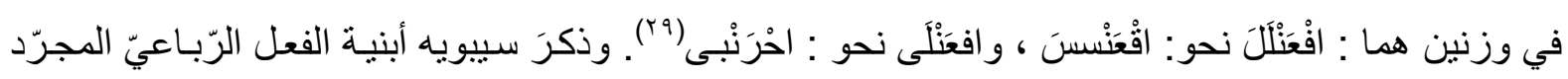

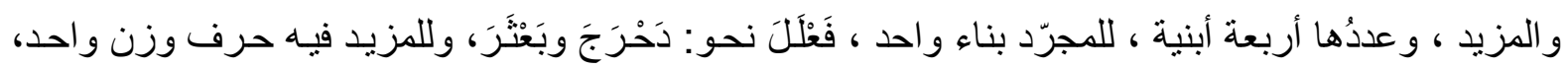

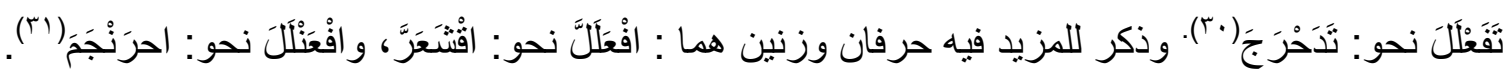
ومن كلّ ما تقدَّمَ تبيَّنَ أنّ عدد أبنية الأفعال الأصول عند سيبويه تسعة عشر بناءً ، منها ثنلاثةُّ للثّلاثيّ المجرد ، وواحد للرّبـاعيّ المجرد ، و اثنـا عشر للثّلاثيّ المزيد ، وثلاثتة للرّبـاعيّ المزيد ، و وعددُ أبنية الأفعـال الملحقة عنده سبعة عشر بناءً ، منها سبعة ملحقة بالرّباعيّ المجرّد ، و وعرة ملحقة بالرّباعيّ المزيد. قالَ سيبويه بعد أن ذكر أبنية الأفعال : (فهذا جميع ما أُلحِقَ من بنات الثّّلاثة بينات الأربعة ، مزيدة أو غير مزيدة ، فقد بيَّنَ أمثلة الأفعال كلّها من بنات الثّّلاثة مزيدة أو غير مزيدة ، فما جاوزَ هذه الأمثلة ، فليس من كلام

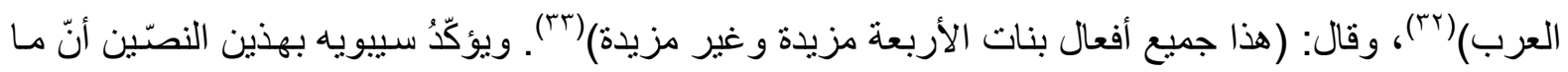
ذكره من أبنية الأفعال الأصول و الملحقة ، وأمثلتها من الثناثيّ و الرّباعيّ مزيدة و غير مزيدة، هو هصدير حصر شـامل

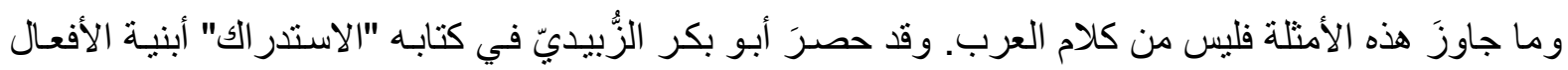
الأصول و الملحقة عند سيبويه في أربعة وثلاثينَ بناءً، و استدركَّكَ عليه أبنية جديدة ، فقال: (فجميعُ أمثلة الأفعال

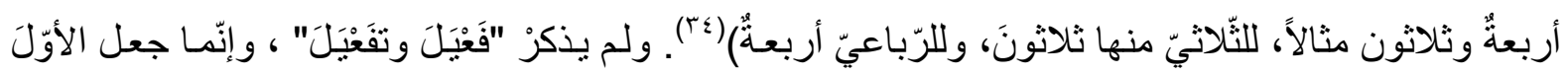

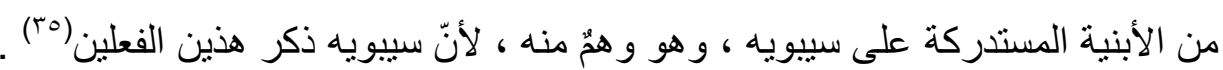
وسنذكر هنا أبنية الأفعال التي استدركها ابن سيده على سيبويه:

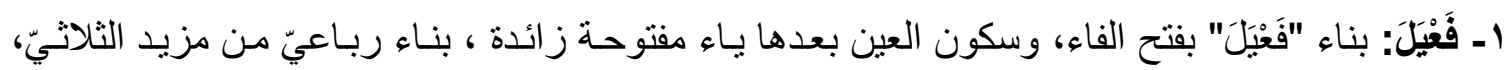

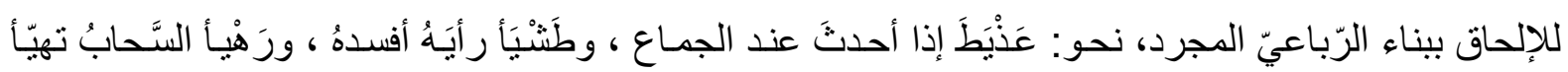

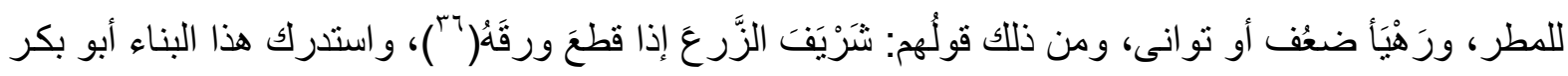

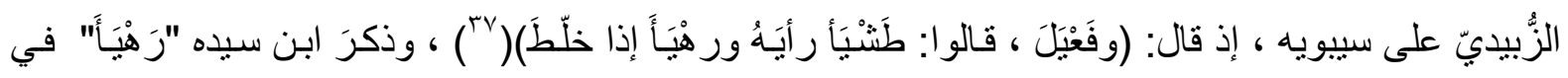

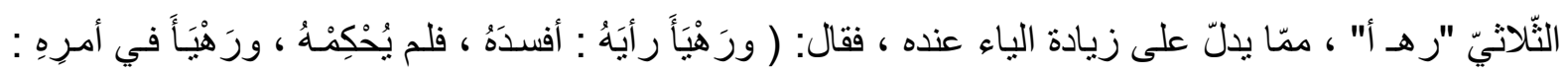

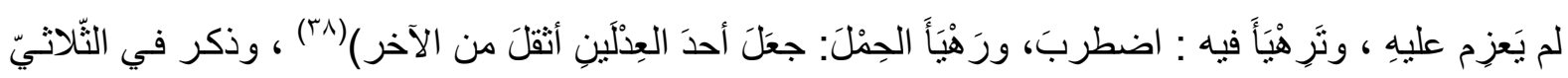

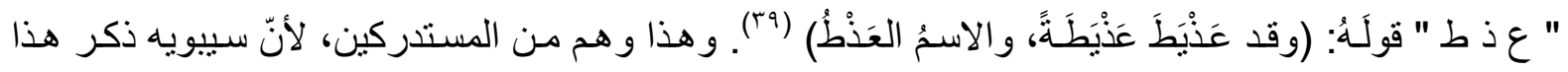

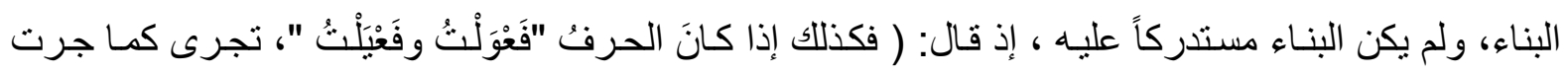

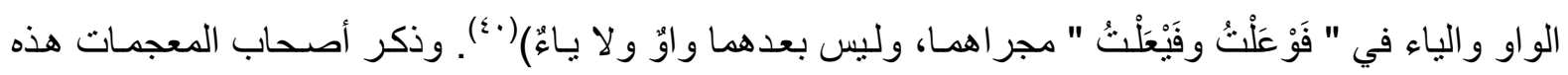

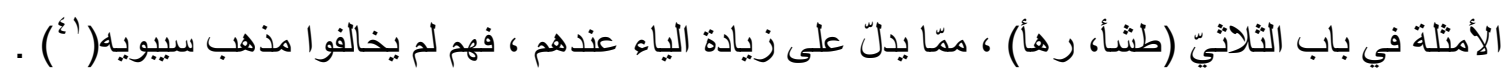
ونُقُل عن أبي علي الفارسي ذهابـه إلىى أن "رَهْيَاً" على وزن "فَعْيَل"، وجعل اليـاء زائدة، و الهمزة أصـلاً،

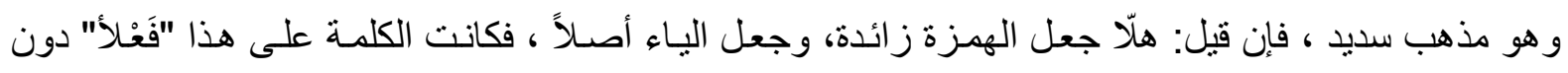

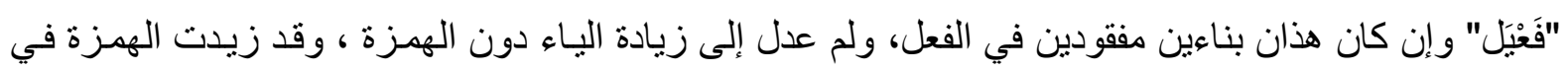

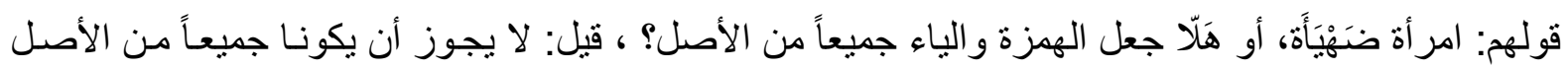


، لأن الياء لا تكون أصلاً في بنات الأربعة إلا في التضـعيف ، نحو "صِيصِيَة" ، وحاحَيْتُ، فلمـا لم يكن بـد من

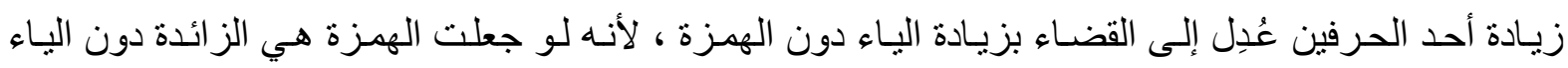

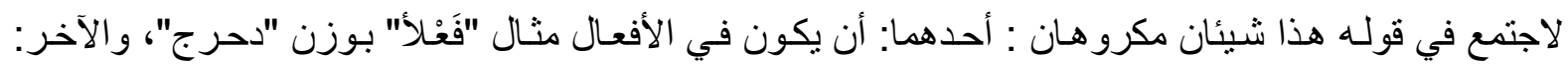

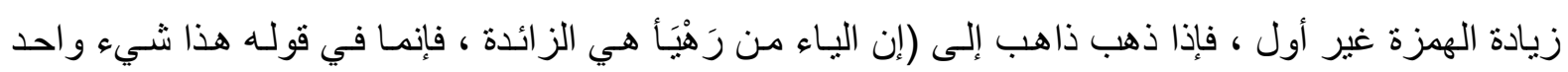

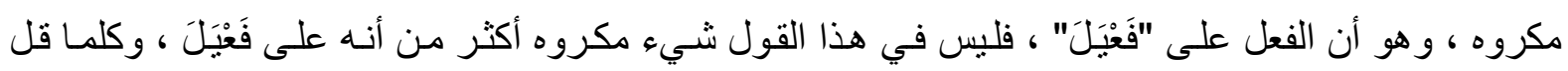

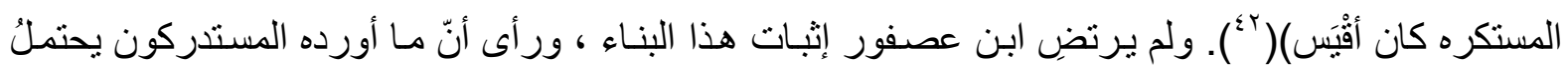
أمرين ، أحدهما: أن تكونَ اليـاء في هذين اللفظين أصـلاً في بنـات الأربعـة ، فيكون وزنُـهُ " فَعْلَلَ" للئلا تؤدّي

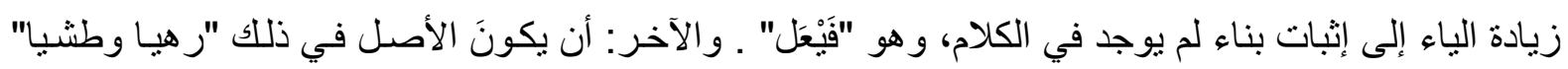

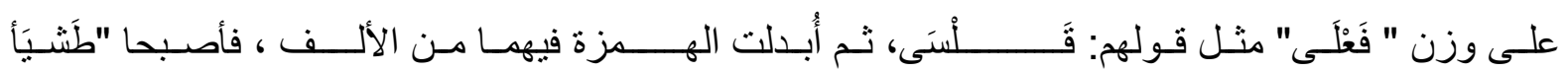

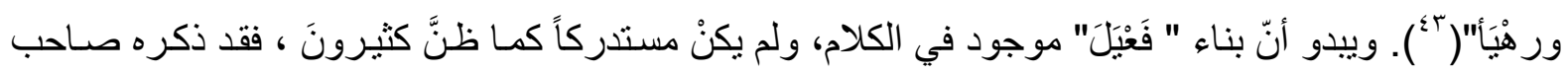

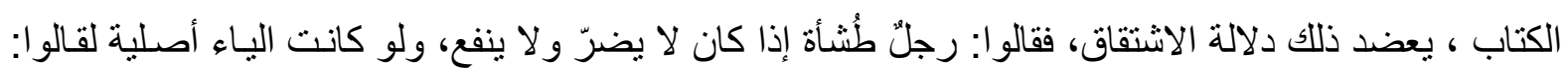
طُشيأة ، يز اد على ذلك أنّ الياء من حروف الزيادة ، وسقوطها في بعض تصـاريف الكلمـة دليل على زيادتها،

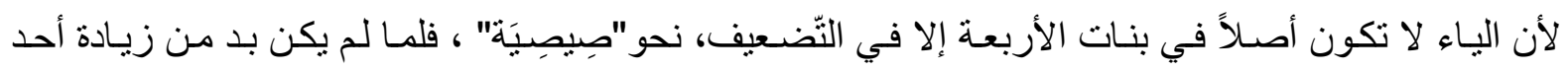

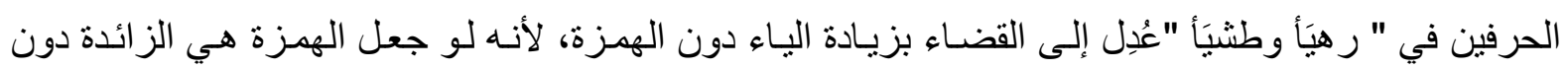

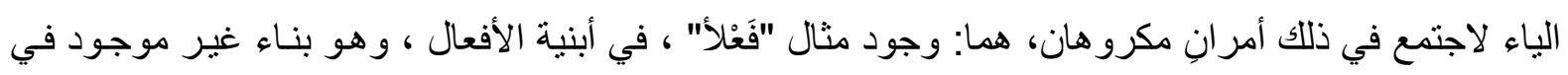
كلام العرب ، وزيادة الهمزة غير أوّل .

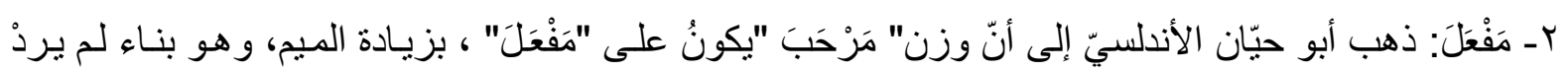

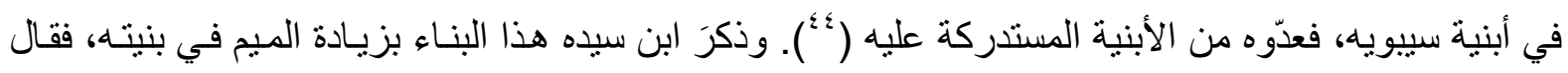

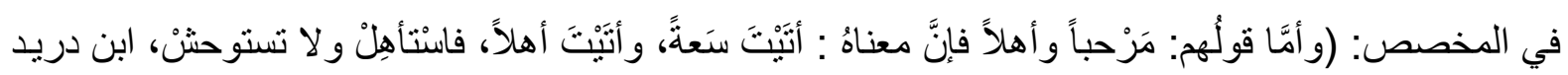

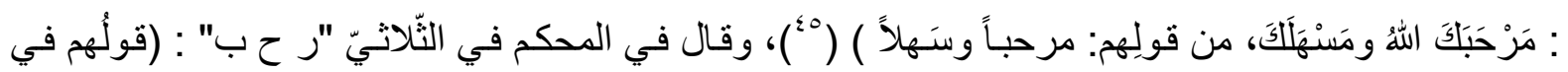

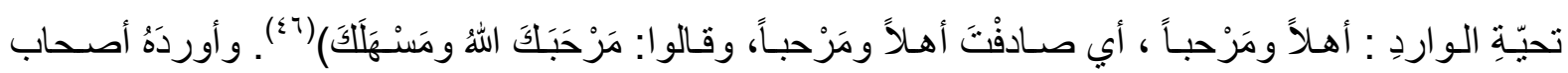

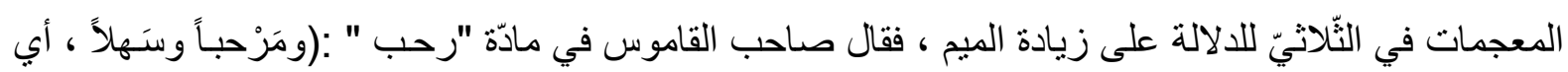

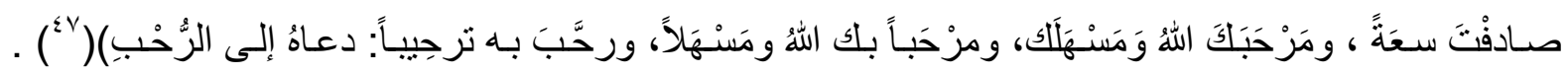

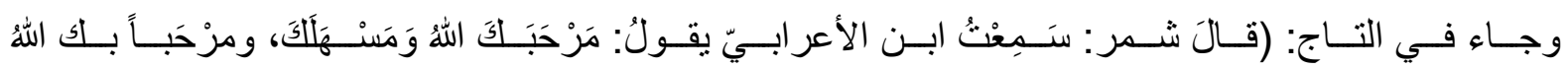

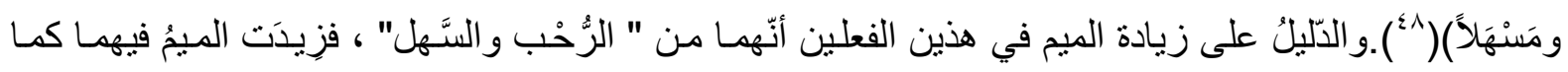

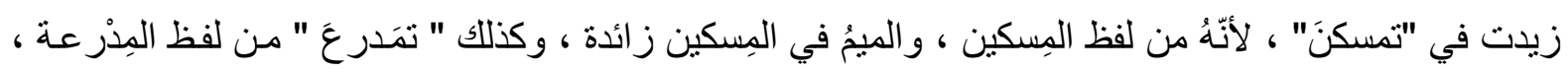

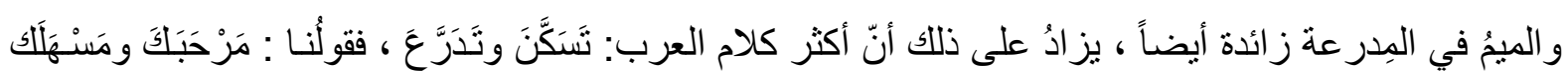

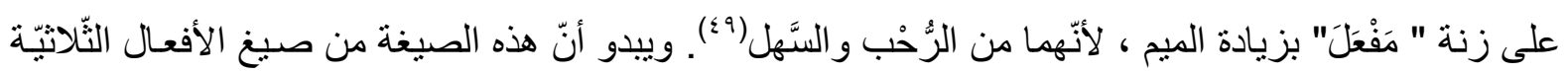
المزيدة ، للإلحساق بالرّبـاعيّ المحرد، وهي صيغة غريبـة وغير معروفة ، يدلّ على ذلك ندرثُها في الكـلام

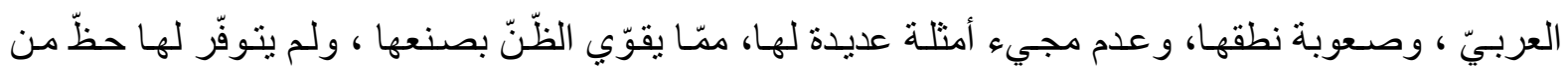

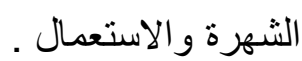




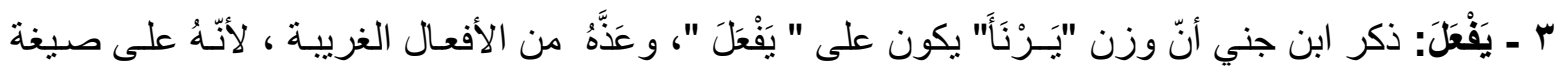

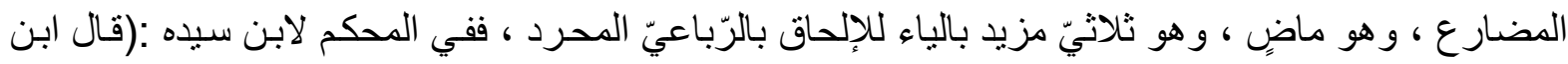

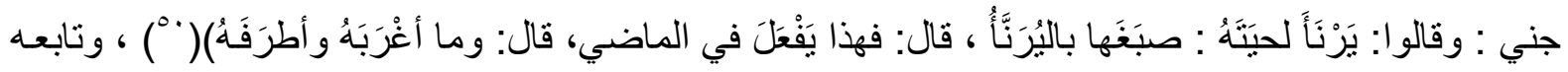

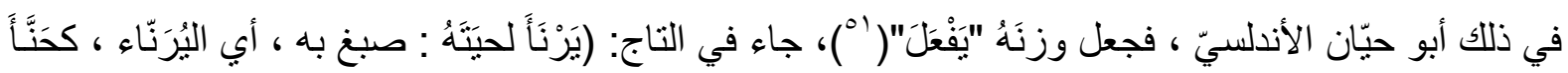

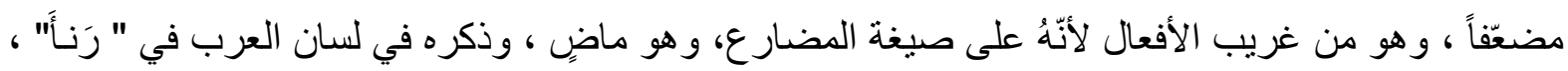

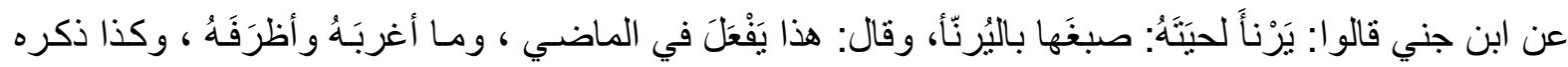

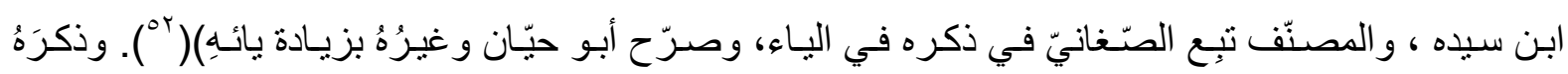

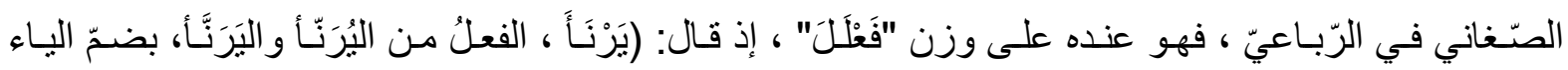

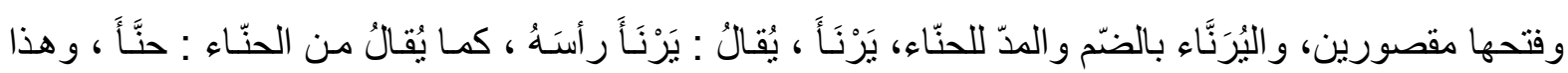

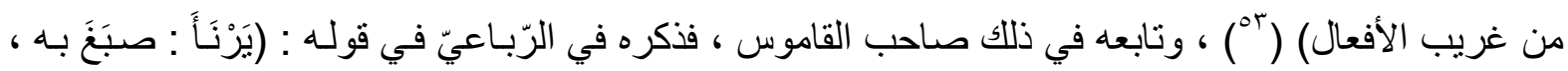

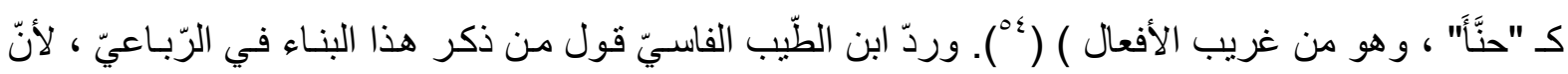

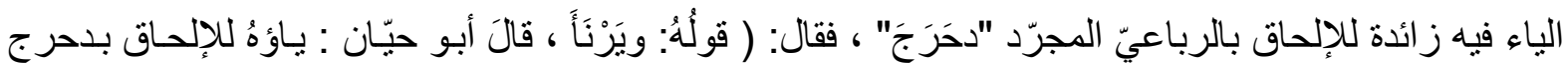

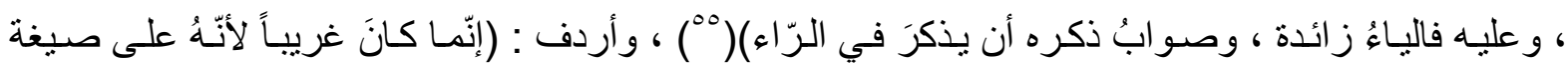

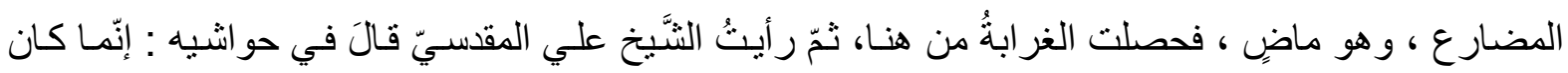

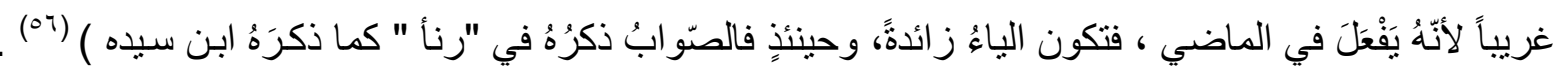

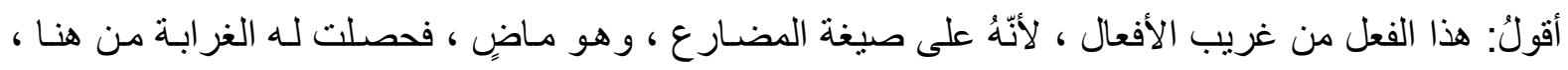

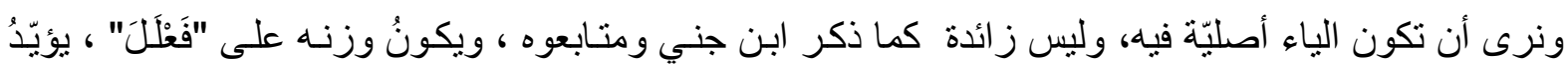

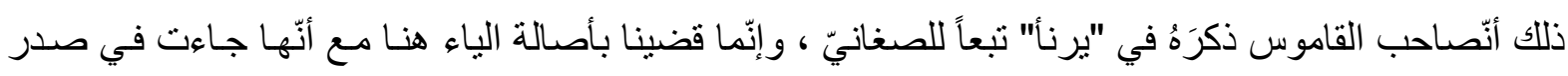

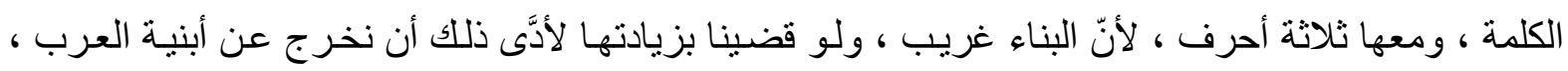

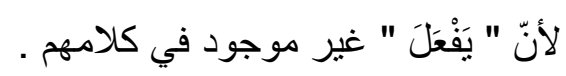

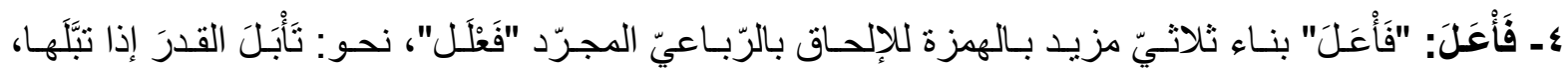

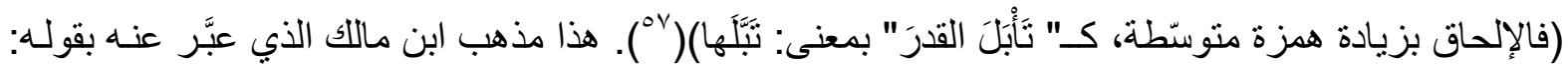

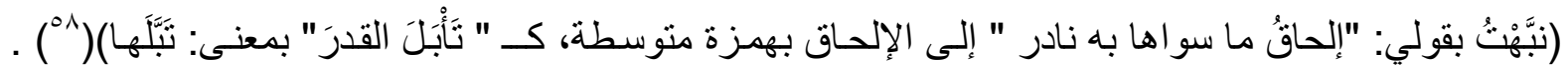

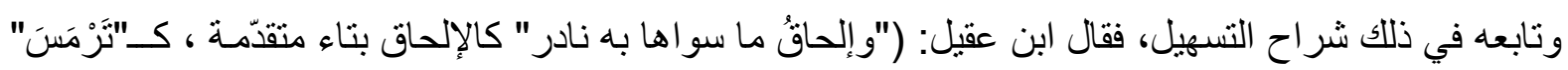

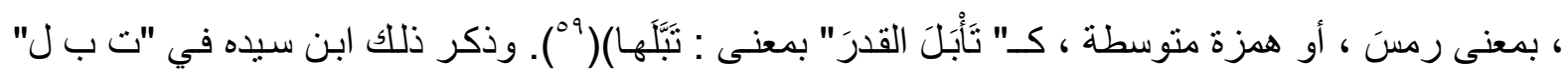

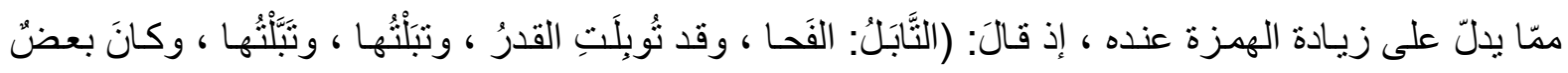

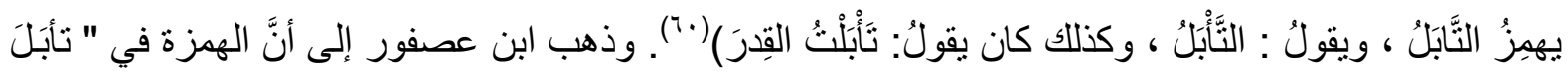

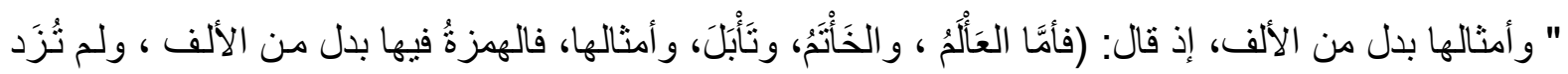

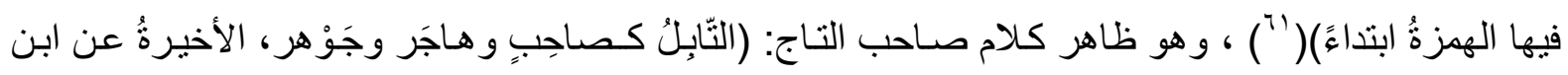

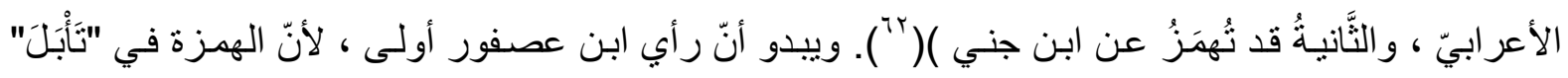


وأمثالها ليست زائدة ابتداء، و إنّما هي بدل عن الألف، لأنّهم قالو ا "تابَلَّ" ، لقّلّة زيـادة الهمزة غير أوّل، ( فلمّا

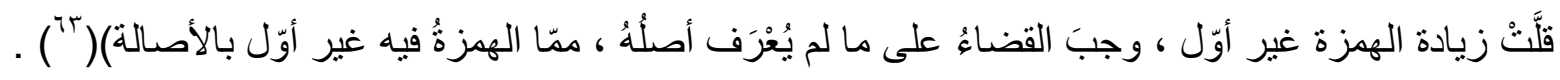

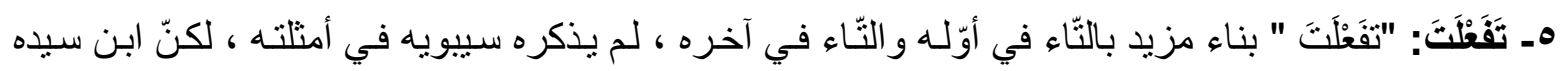

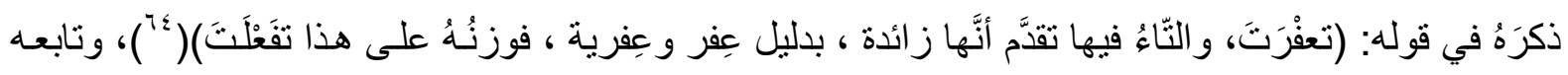

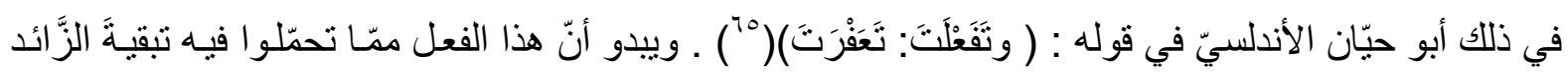

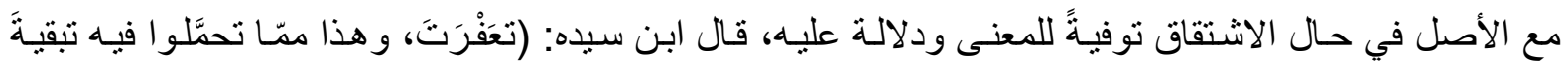

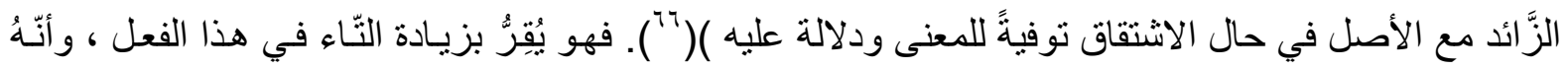

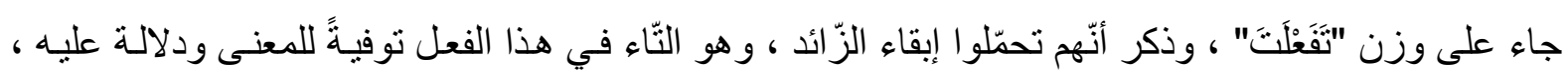

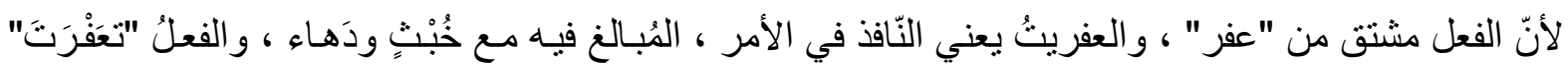

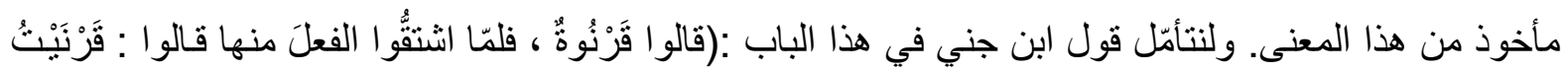

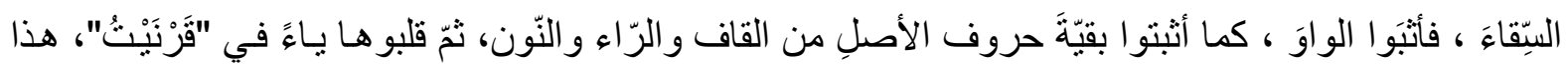

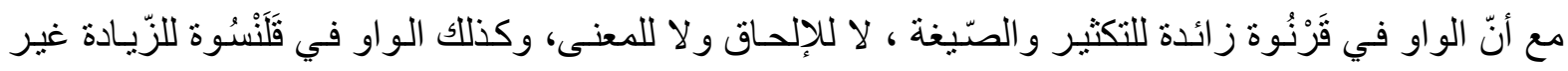

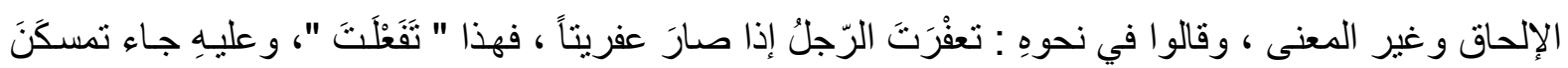

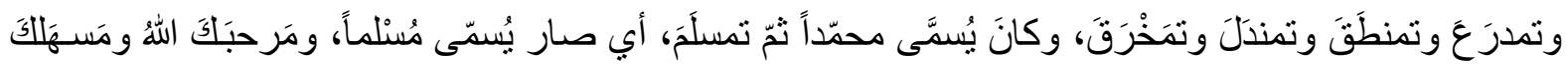

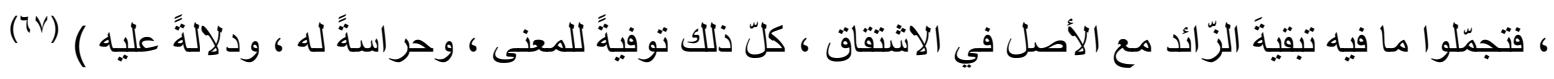

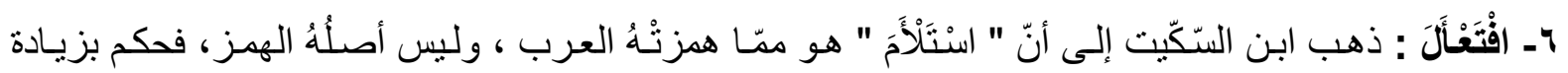

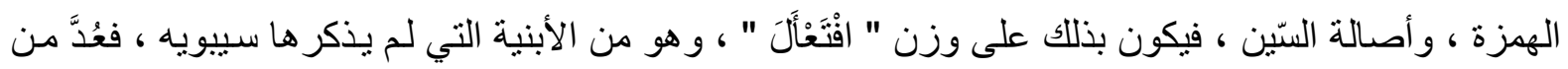

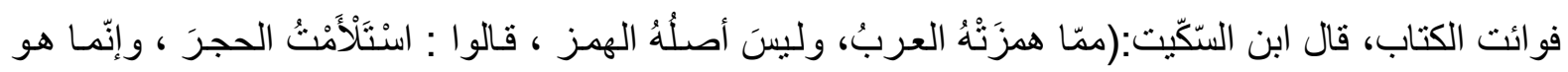

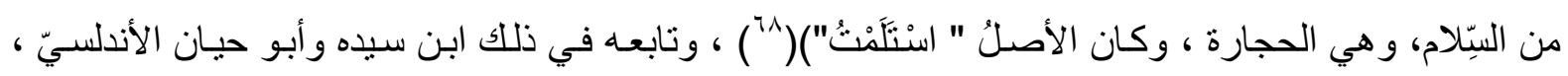

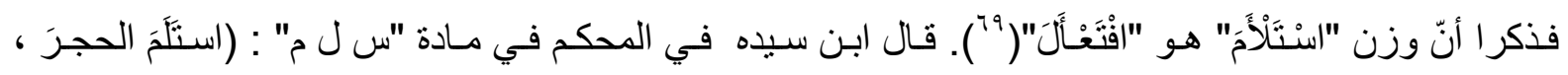

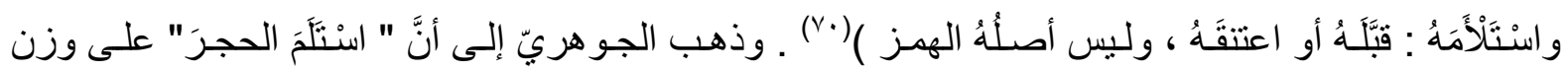

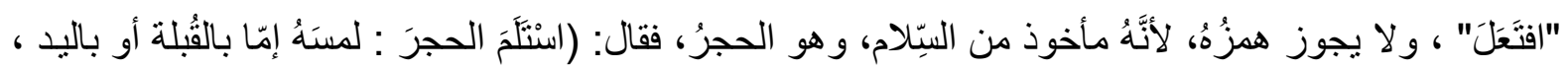

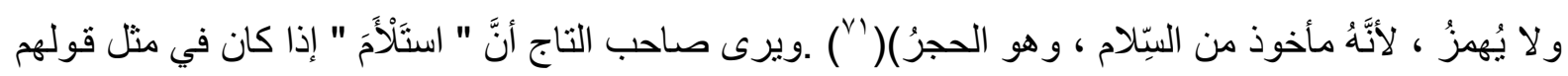

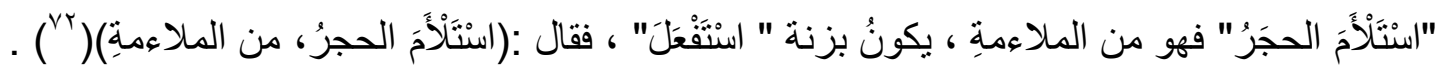

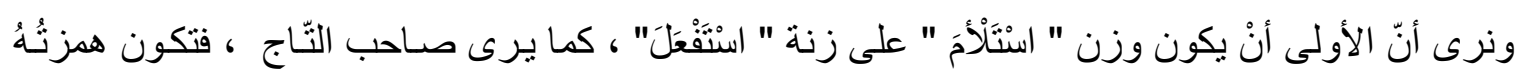

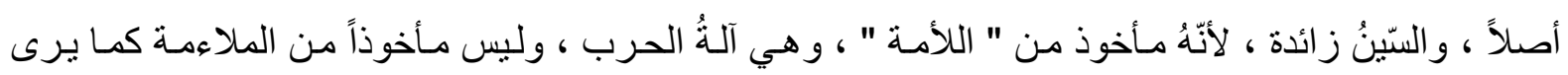

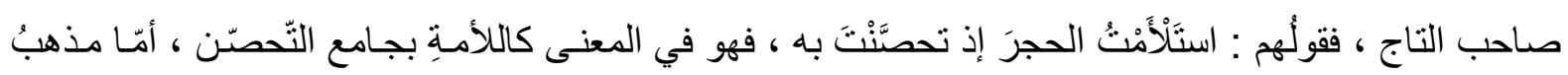

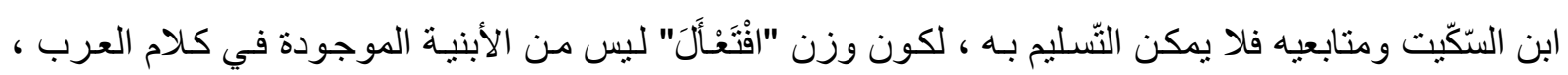

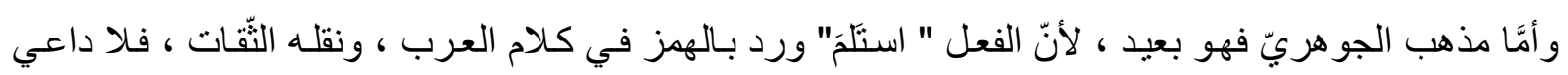




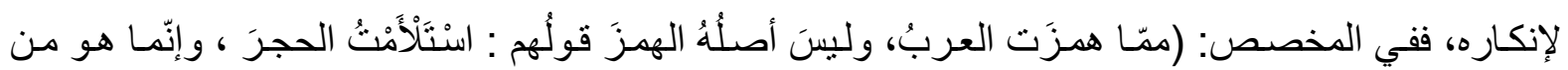

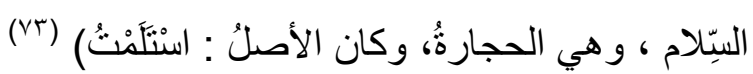

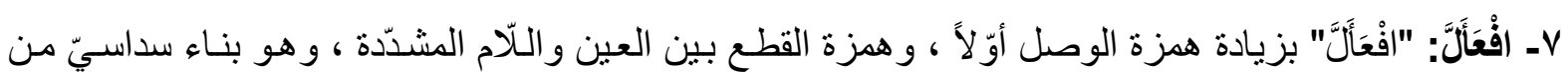

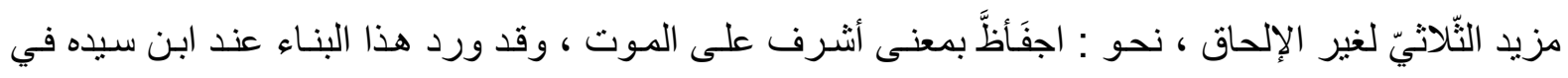

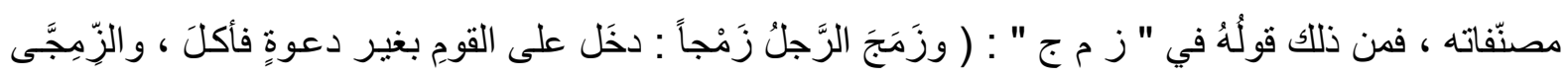

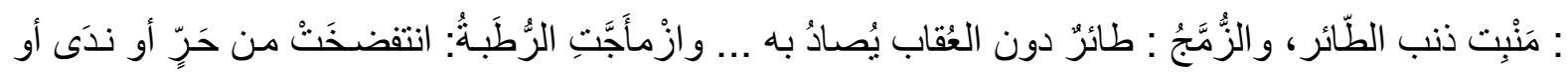

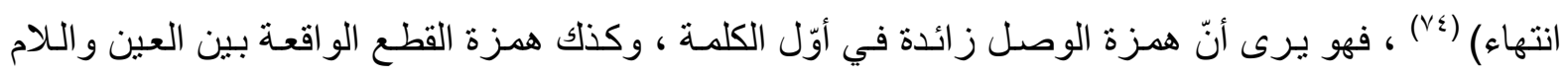

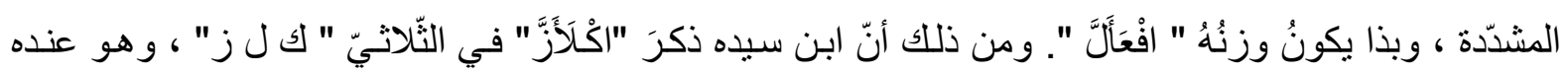

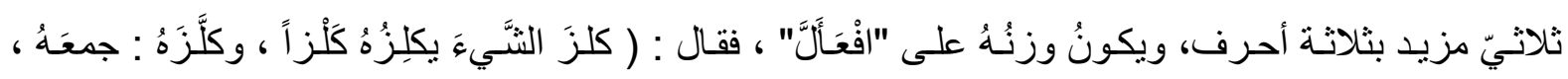

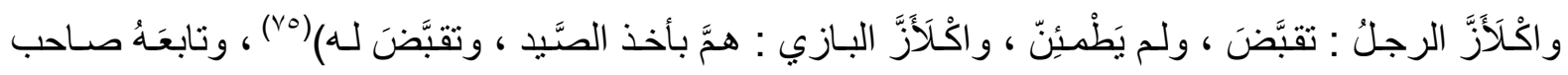

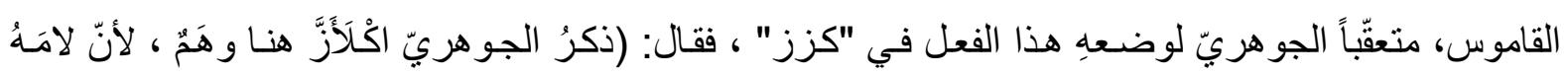

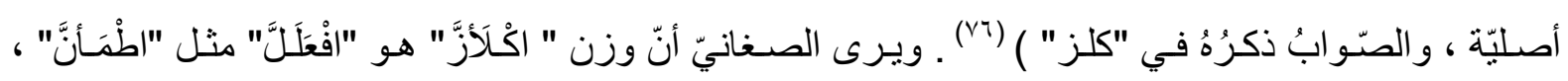

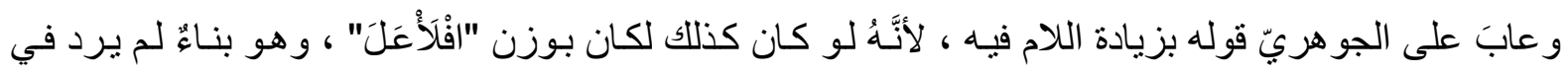

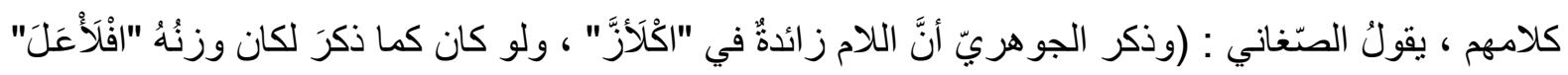

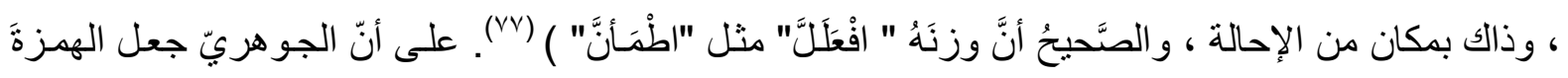

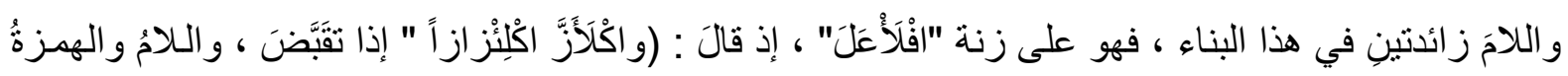

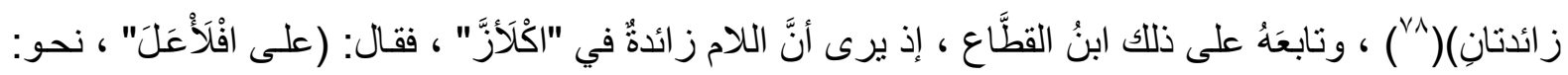

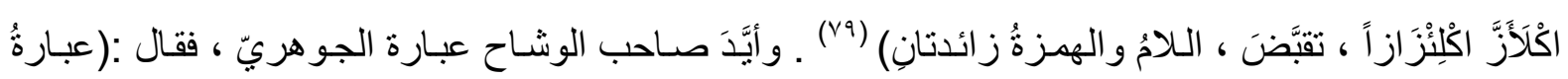

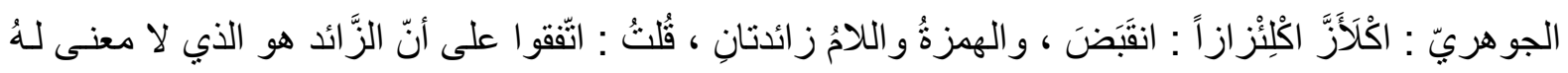

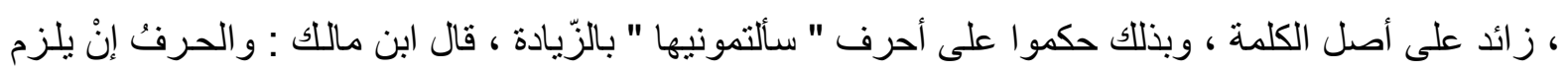

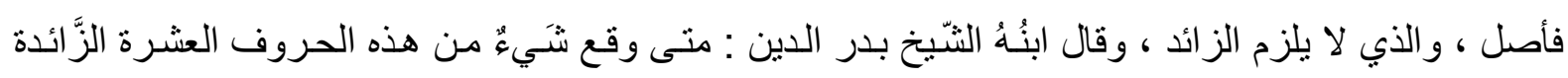

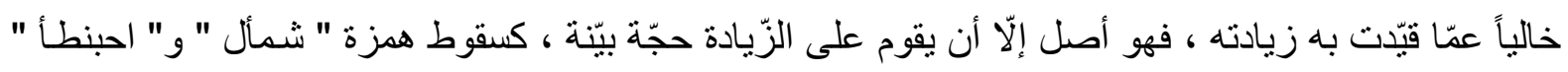

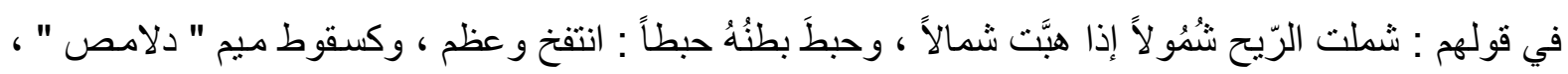

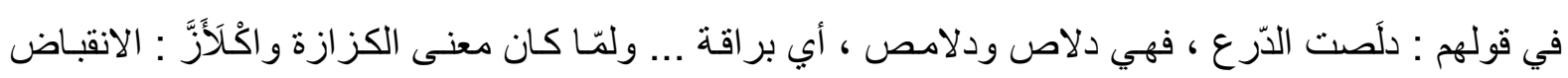

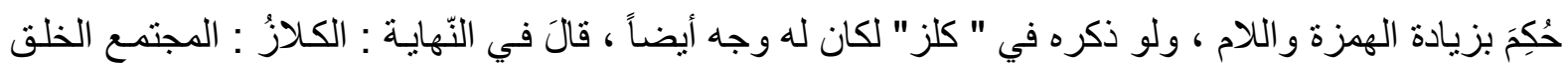

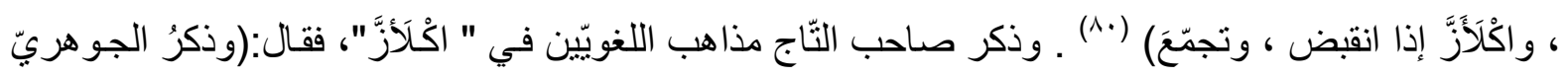

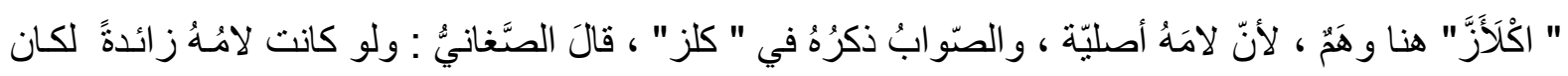

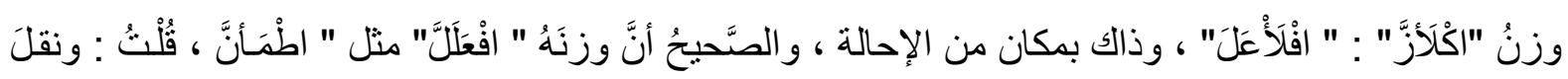

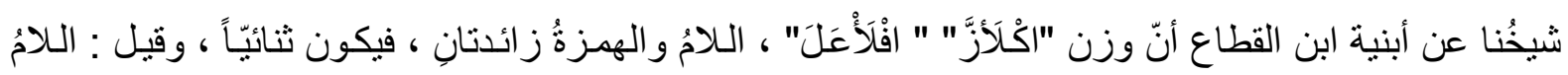

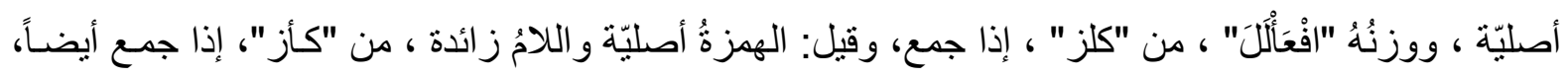

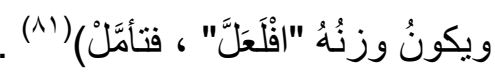




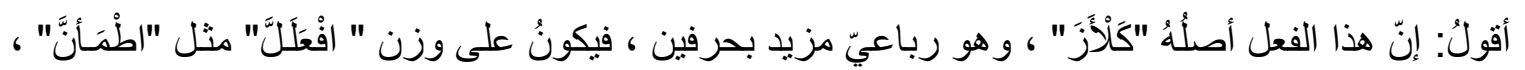

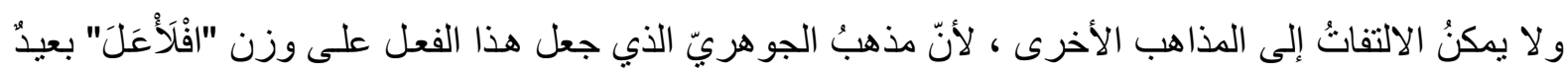

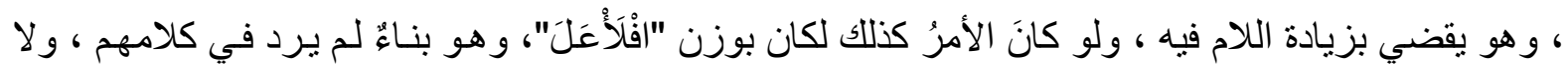

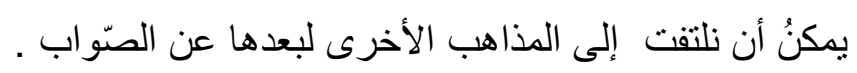

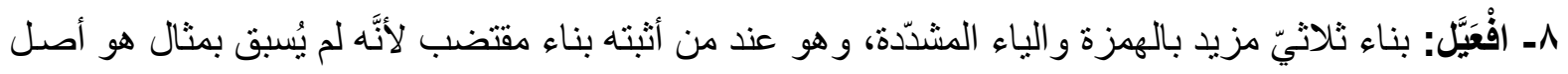

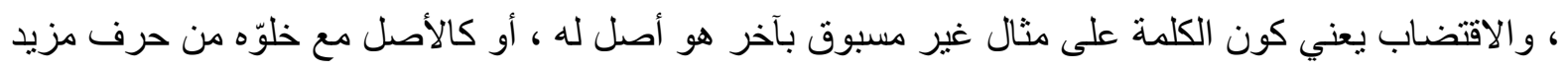

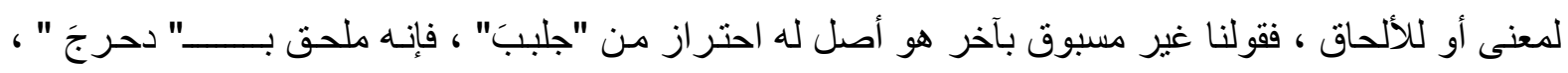

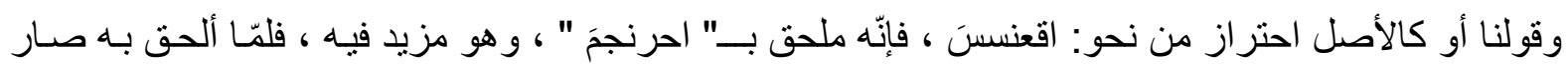

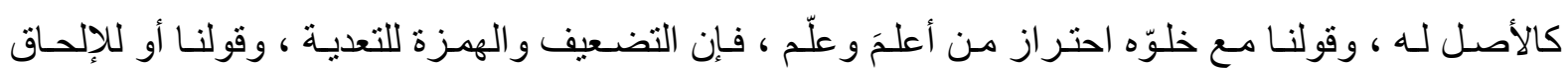

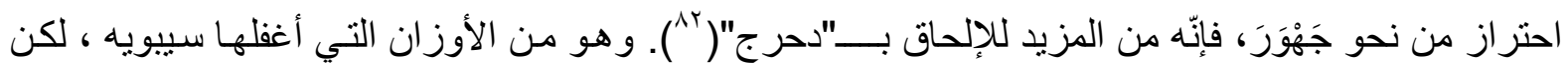

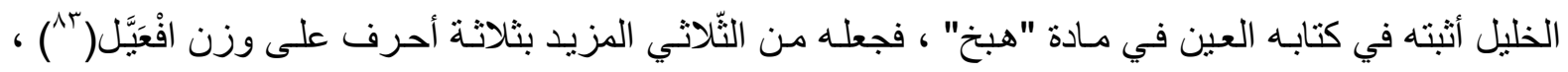

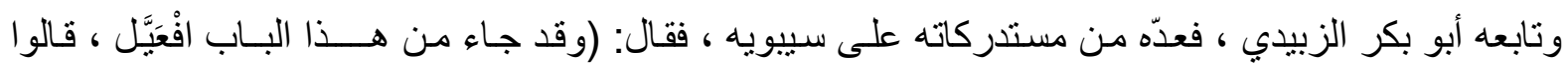

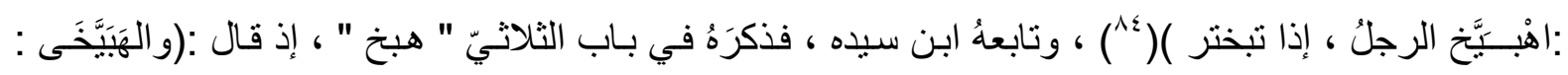

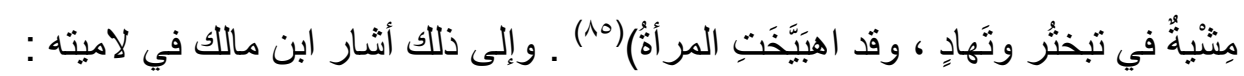

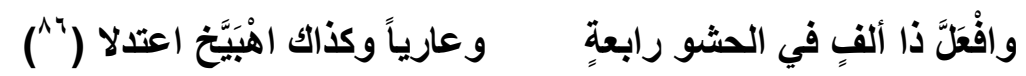

أي: ومن الأفعال المزيدة " افعالَّ" مزيد بهمزة الوصل و ألف رابعة بين العين واللام المضعفة وكذللك افعلّ الكّل

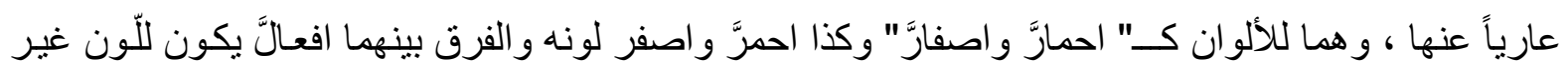

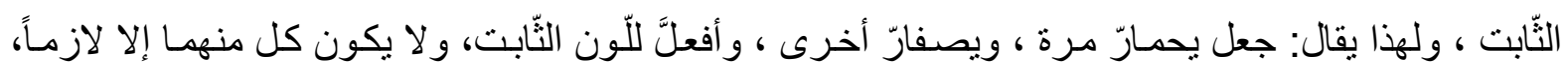

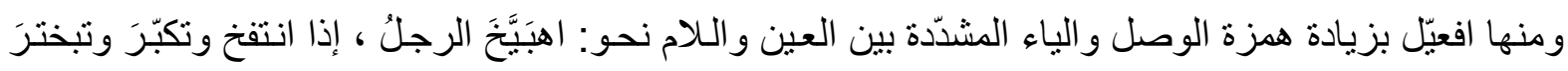

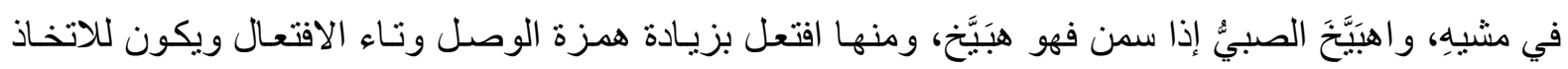

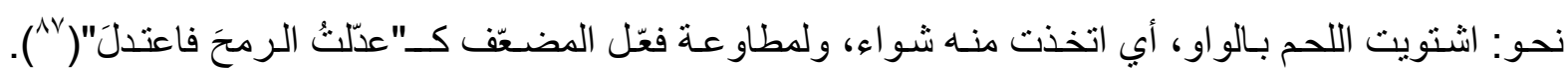

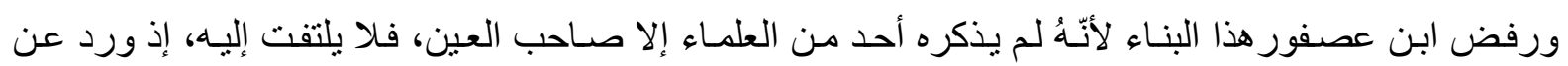

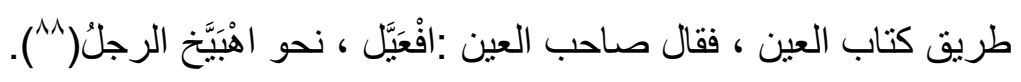
و القول بوجود هذا البناء أولى من إنكاره ، لأنّ كبار العلماء روَوْهُ في مصنفاتهم ، فصاحب العين أثنتهـه ،

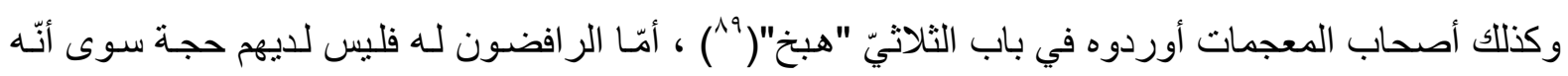

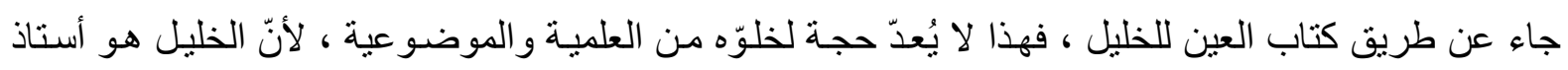

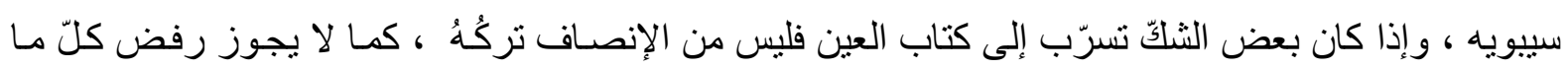
جاء فيه.

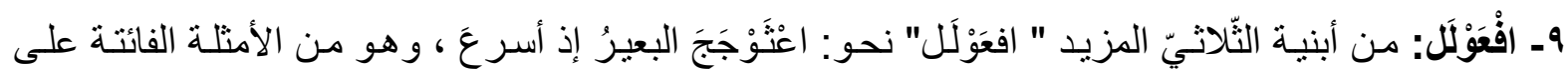

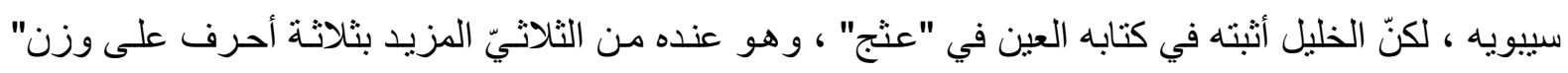




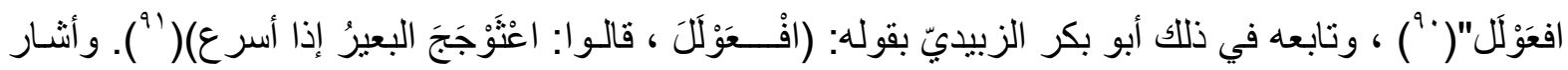
إلى ذللك ابن مالك بقوله:

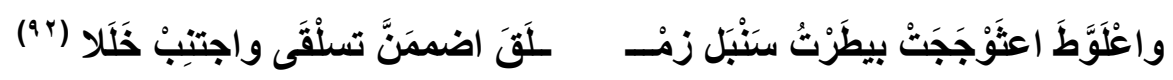

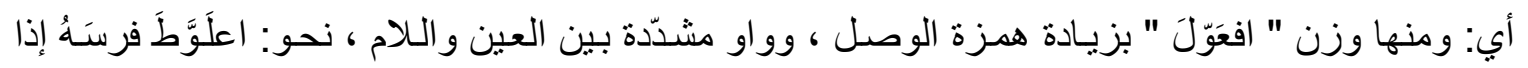

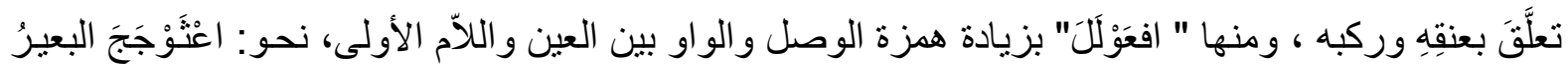

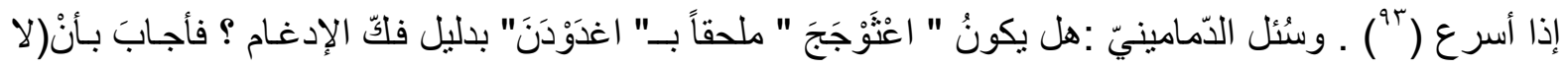

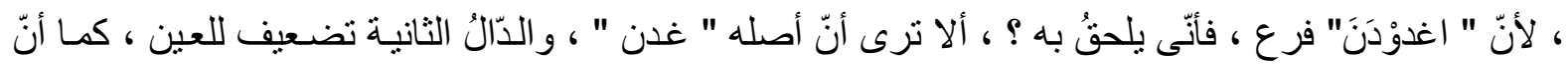

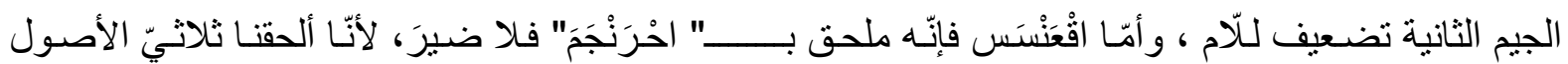
برباعيّ الأصول ، و وأمّا إلحاق ثلاثيّ الأصول بثلاثيّ الأصول فلا اتِجاةَ له ، فقال: أفيكونُ ملحقاً بـــــ" احْرَنْجَم

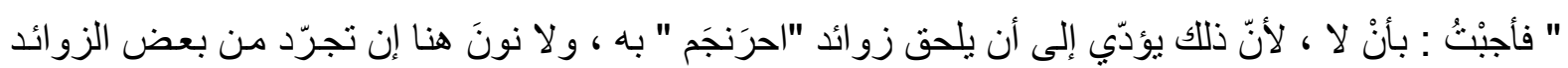

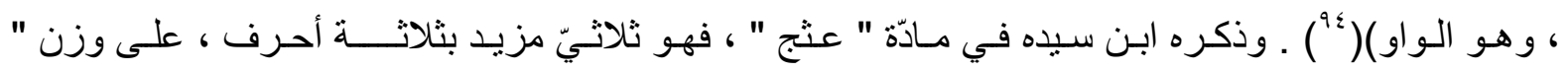

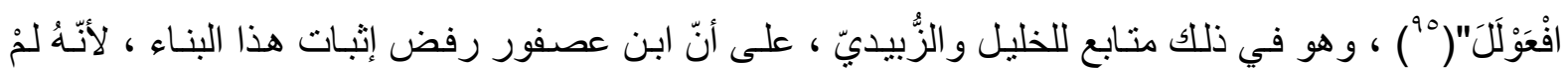

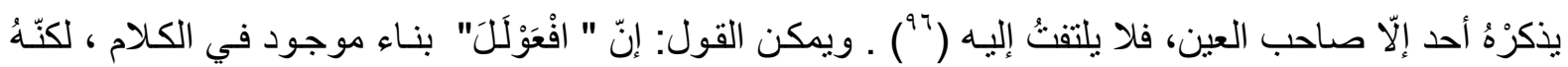

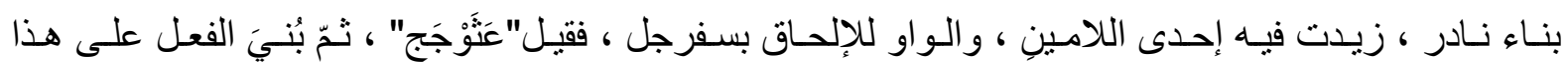

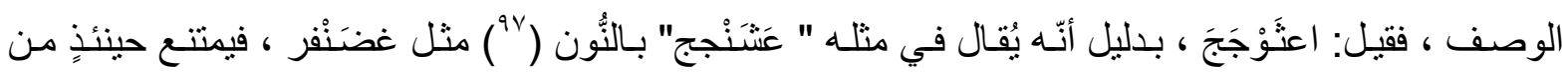

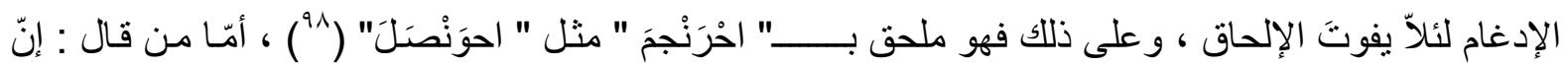

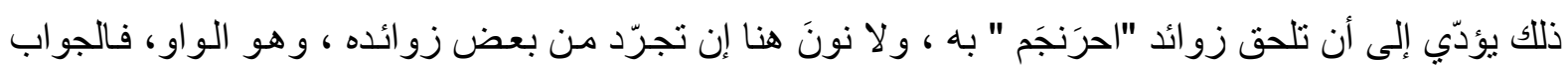

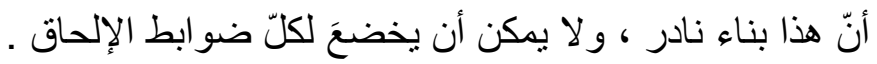

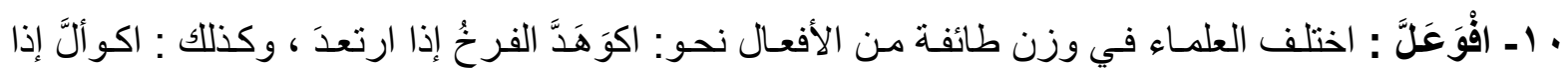

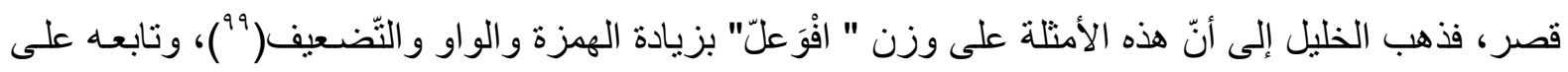

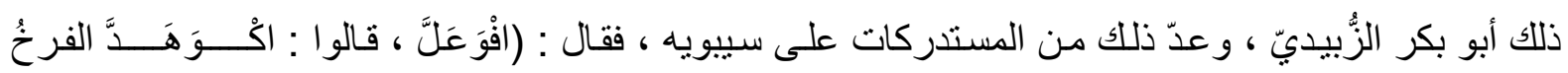

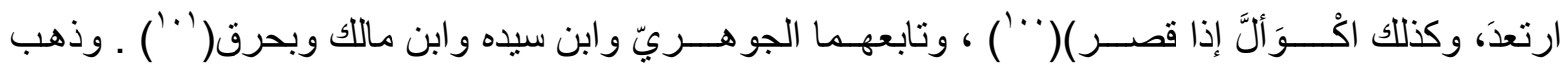

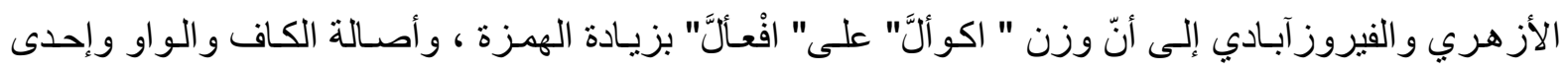

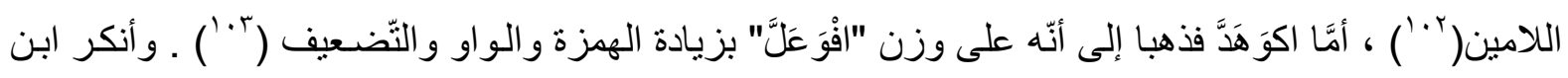

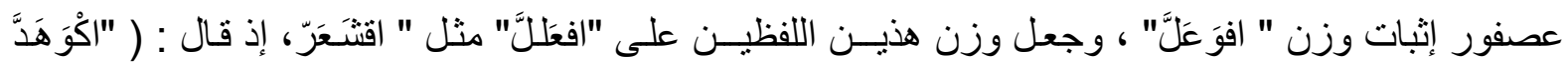

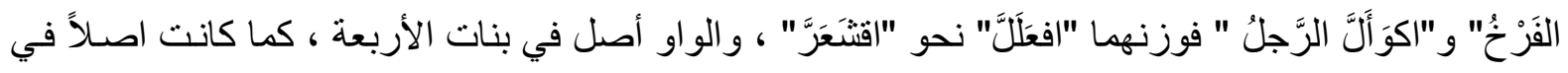

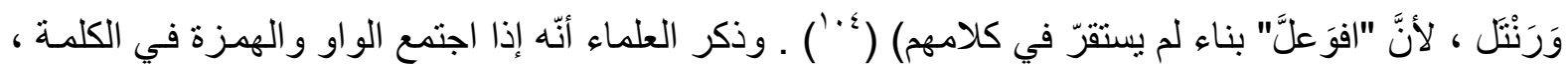

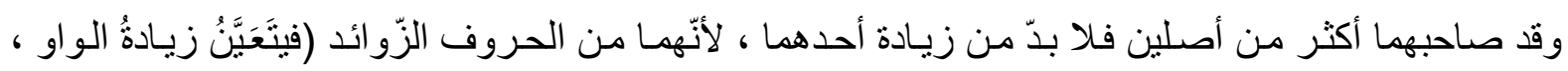

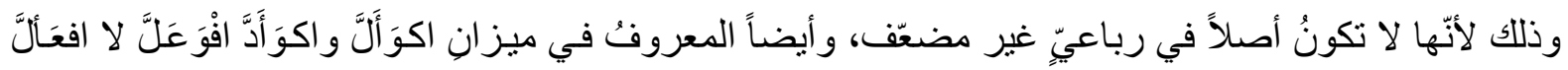

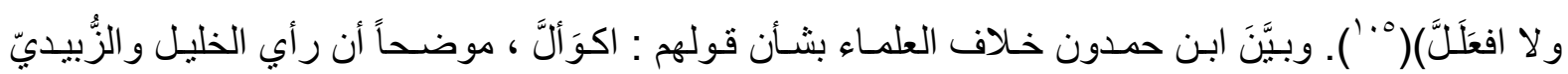


أولى، إذ قال: (قوله" و الواو بين الفاء و العين" ، هذا صريح في أنَّ همزة "اكْوَأَلَّ " هي عين الكلمة ، وبه صرّّح

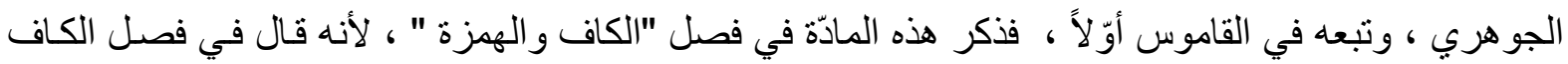

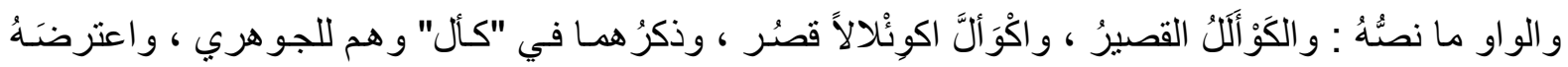

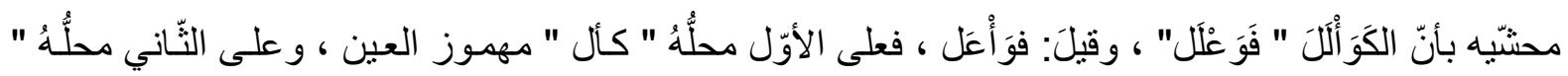

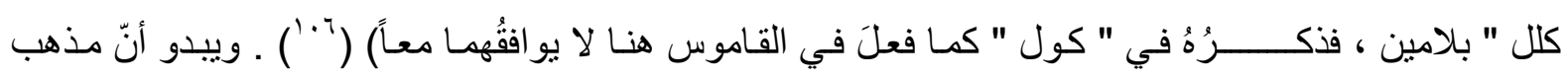

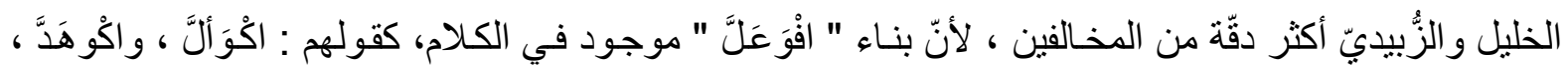
بزيادة الهمزة و الواو و التضعيف ، أمّا ما ذهب إليه ابن عصفور من قوله بأصالة الواو في هذا البناء فلا يمكن

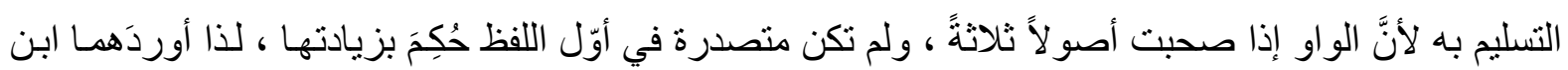

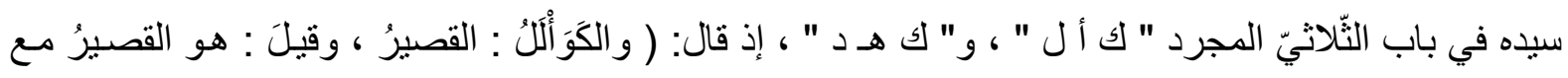

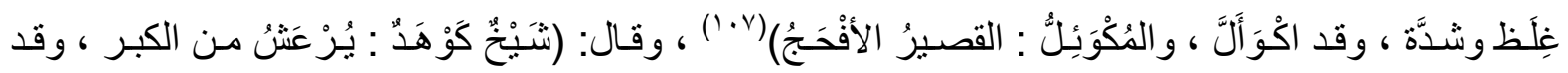

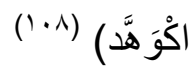

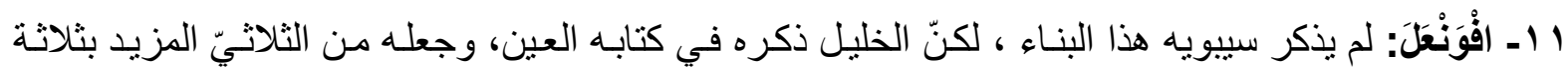

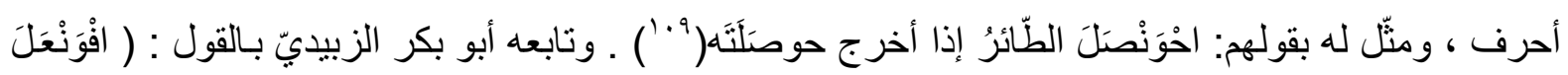

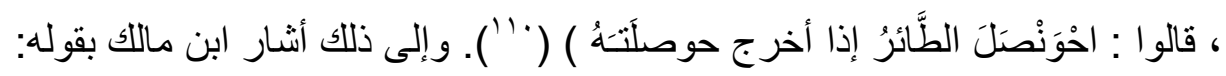

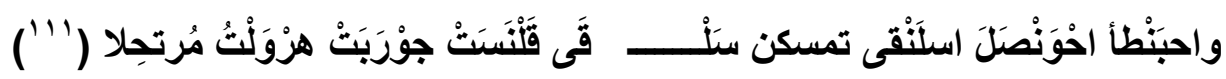

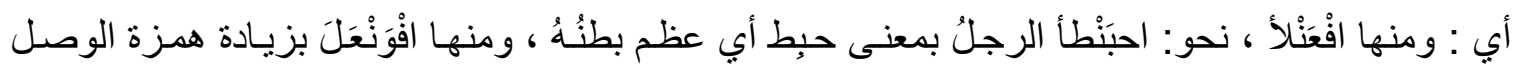
و الواو و النون بين الفاء والعين نحو: احْوَنْصَل الطائر إذا ثنى عنقه وأخرج حوصلته، وهو مستقر الطعام منـه

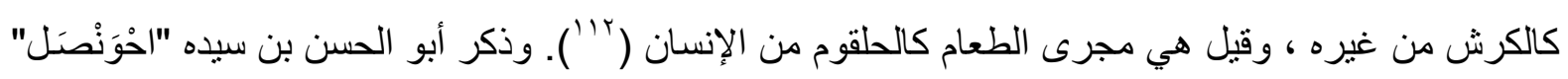

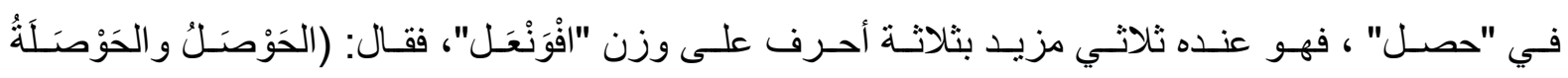

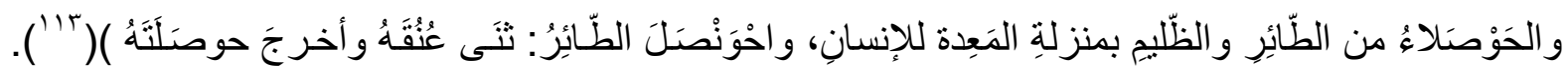

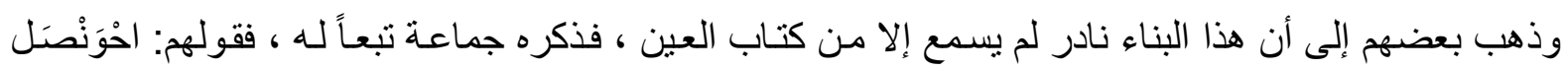

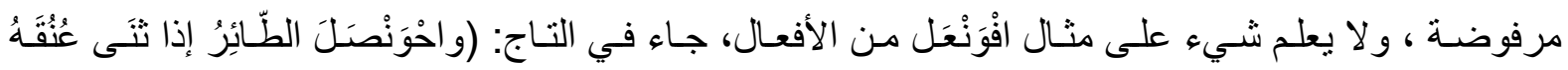

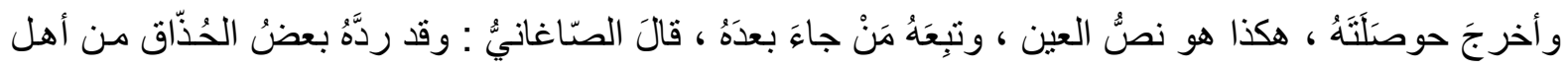

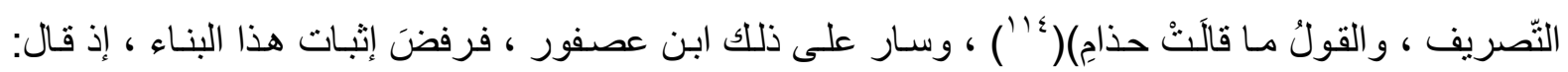

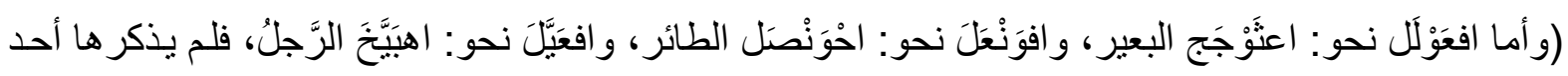

$$
\text { إلا صاحب العين، فلا يلتفت إليها)( (110) . }
$$

أقولُ: ورد الفعلُ "احْوَنْصَلَ" في كتب اللغة،، ونصّ عليه القدماء، وجعلوه من الثنلاثيّ المزيد بثلاثة أحرف ،

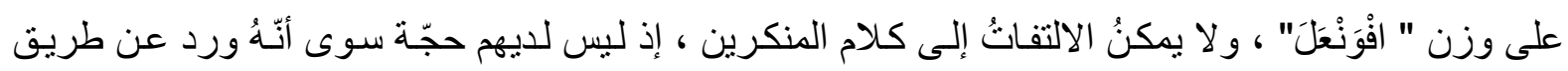
كتاب العين ، و هذا ليس بشيء ، فقد ذكر العلماء أنّه إذا جاء الواو في كلمة ، وقد صـاحبه أكثر من أصلين فلا 


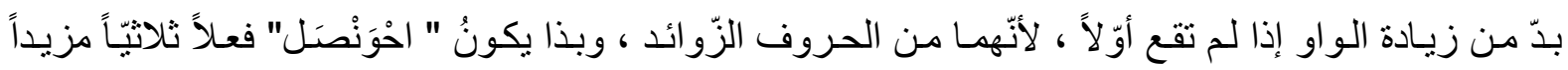
بالهمزة و الواو والنّون ـ

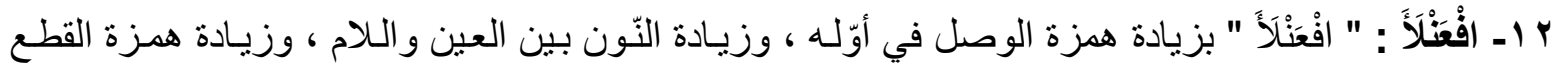

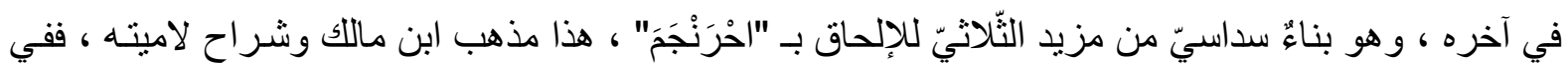

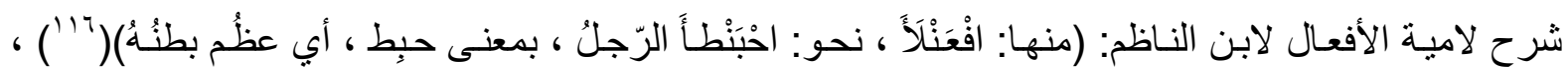

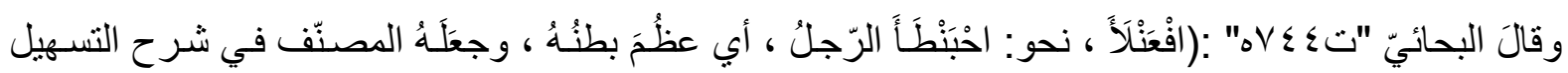

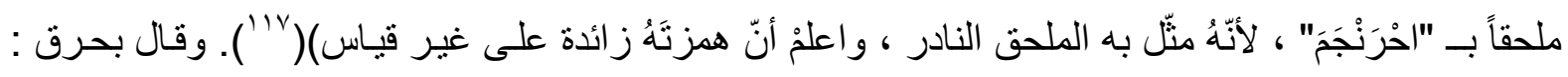

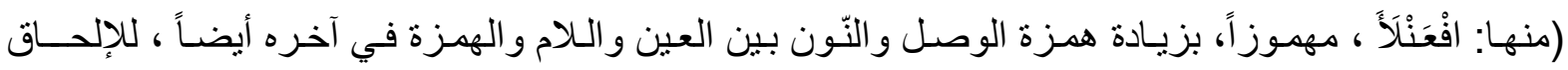

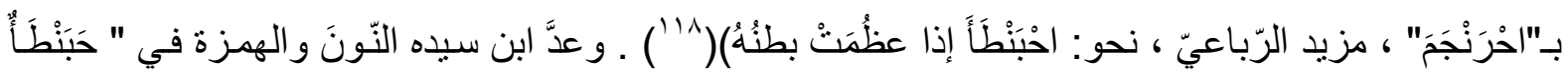

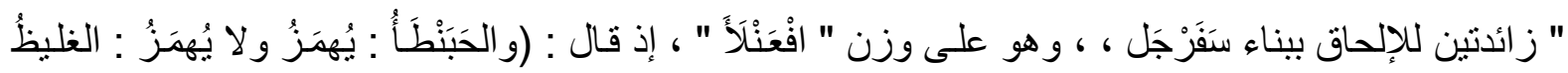

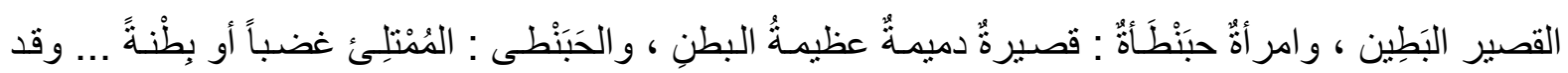

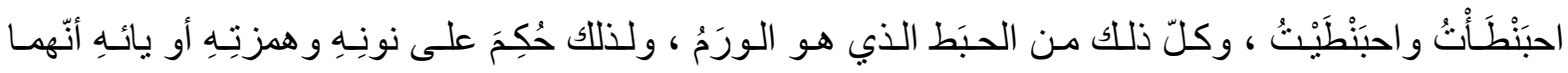

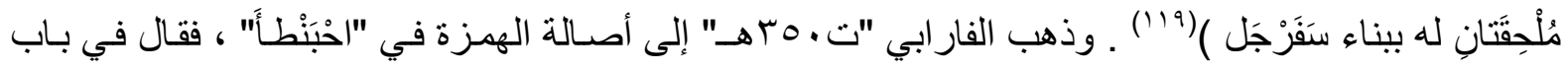

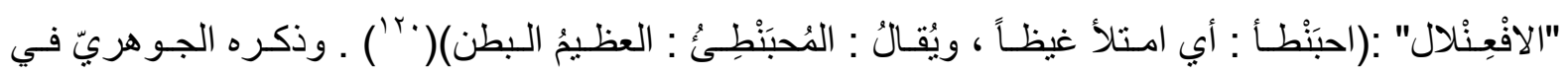

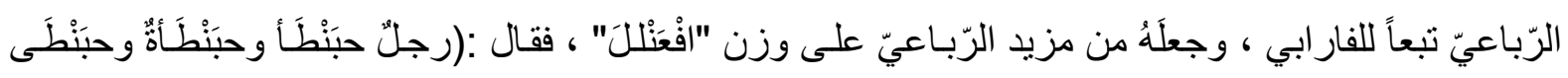

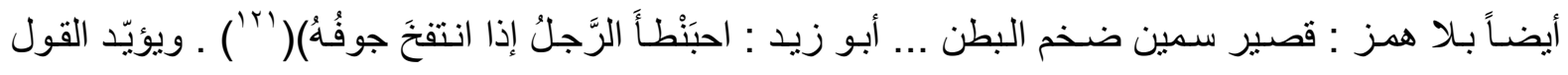

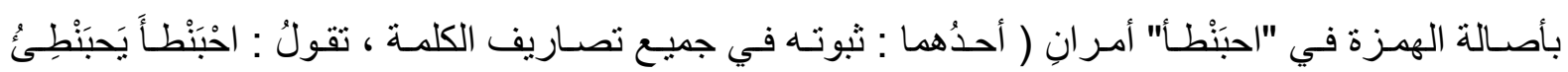

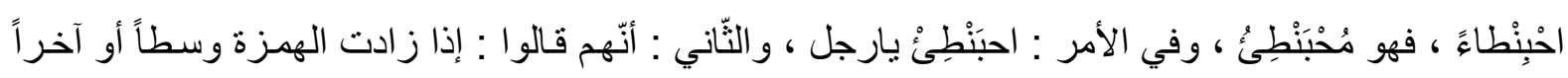

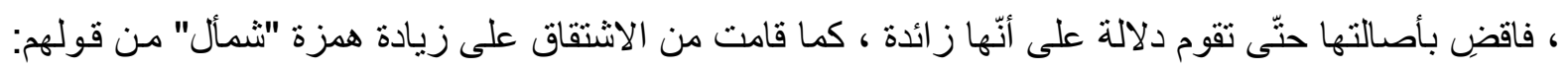

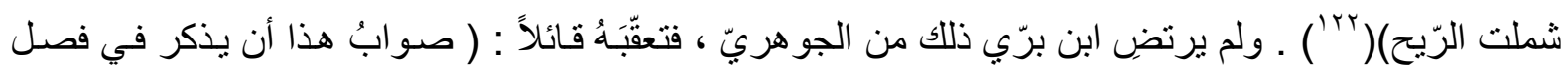

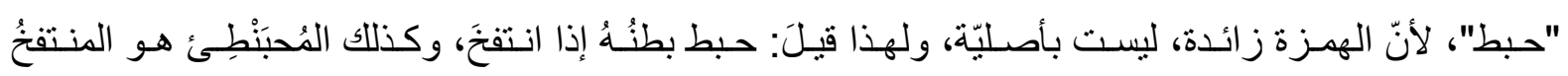

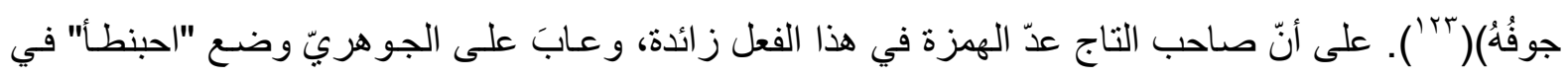

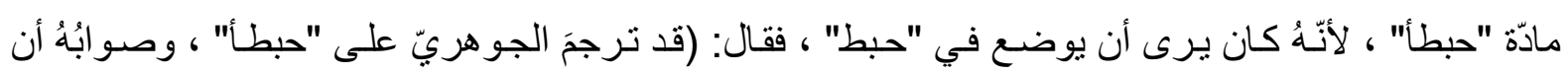

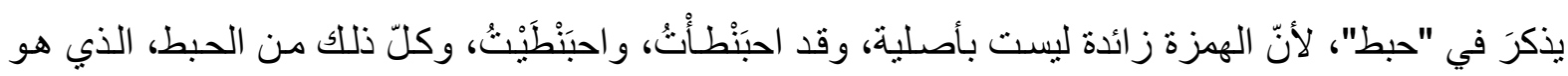

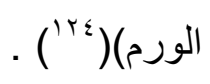

و التمسن صاحب الوشاح العذر للجوهريّ في وضعه "احبنطأ" في مادّة "حبطأ" ، محتجّاً بأنّ قاعدة اللغويين

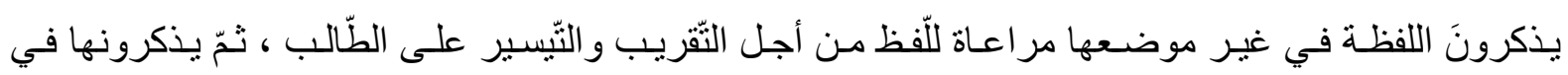

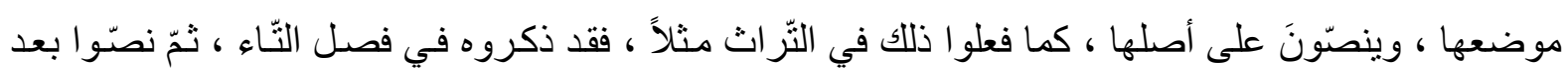

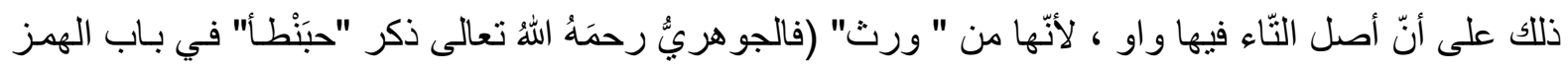

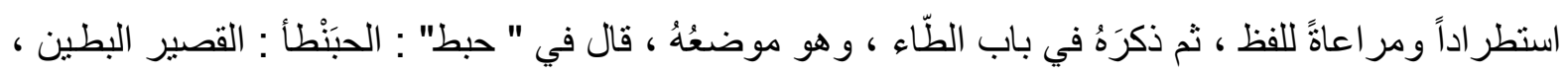




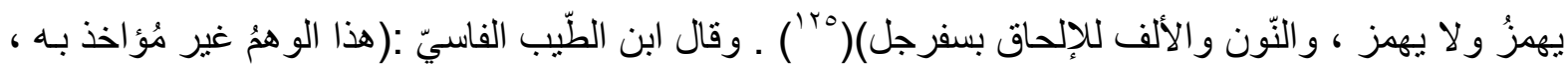

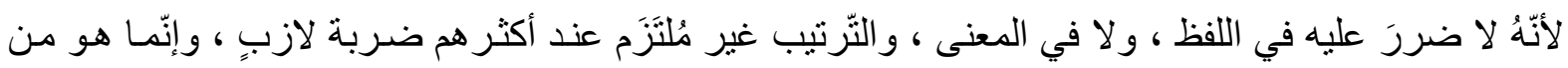

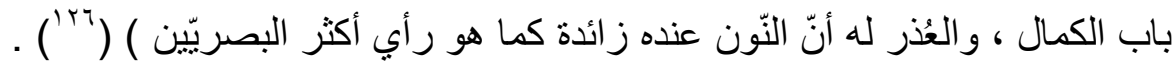

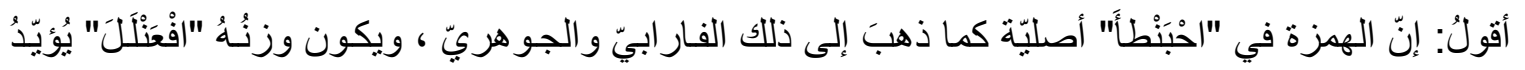

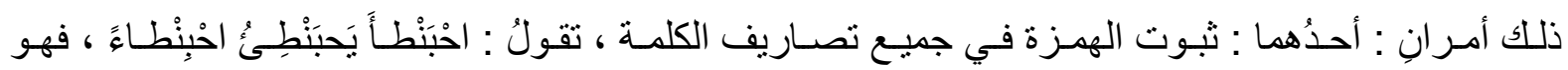

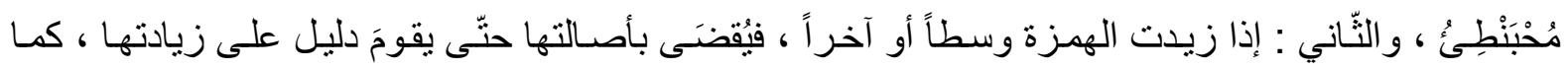
قامت دلالة الاشتقاق على زيادة همزة "شمأل" من قولهم : شملت الرّيح ، فهو من مزيد الرّباعيّ ، كـ " ابرَنْشَقَ

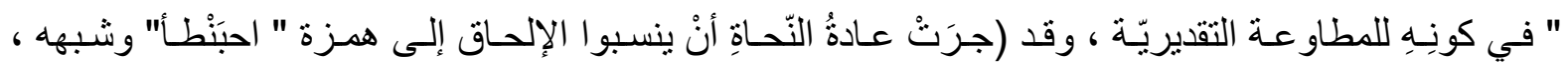
ومر ادُهم كمـا في شرح الكافيـة أنّها بدل من الألف المبدلة من يـاء الإلحاق ، لأنّ الهمزة لا تُز ادُ كذللك ، ومـا

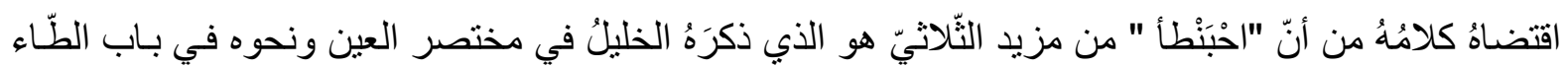

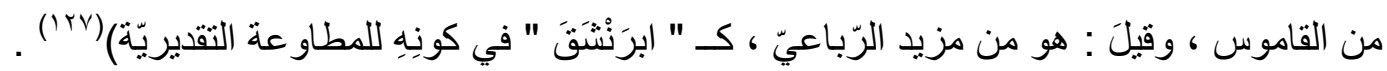

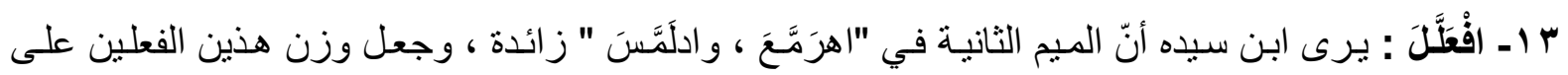

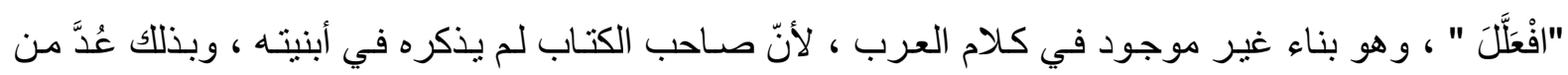

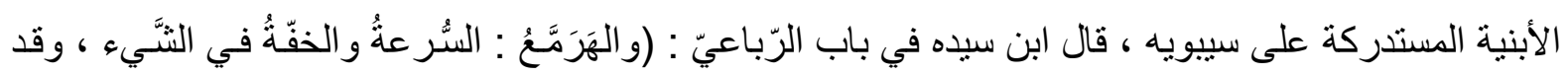

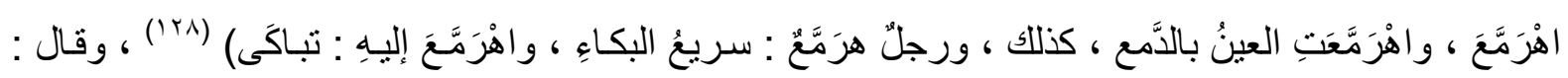

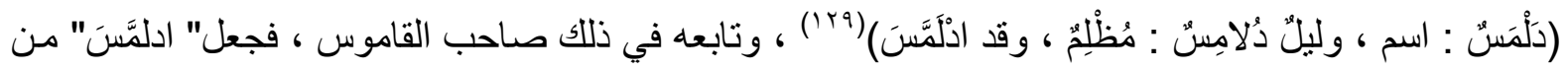

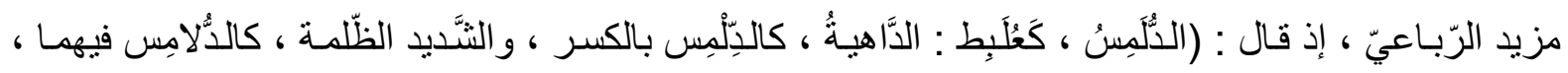

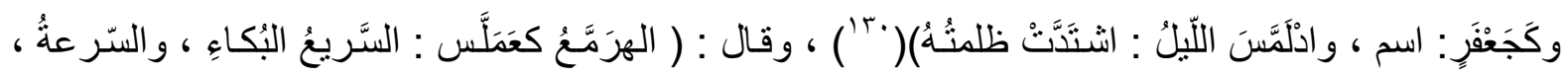

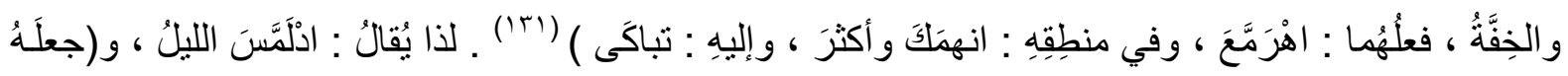

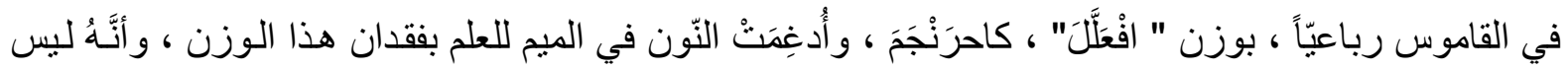

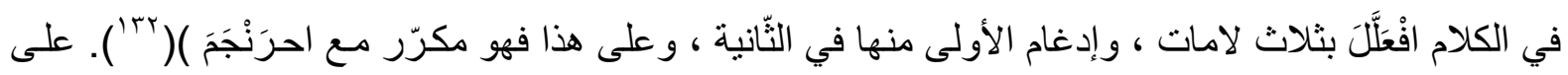

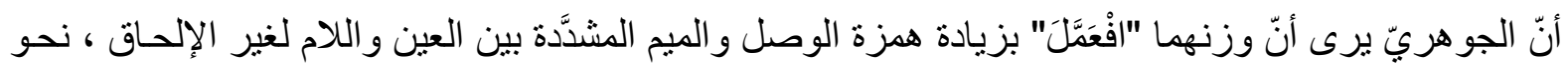

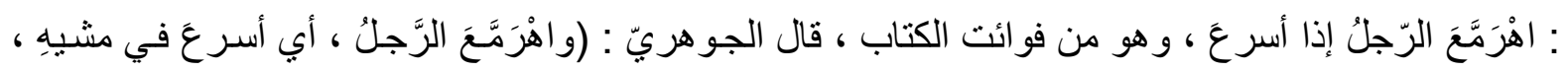

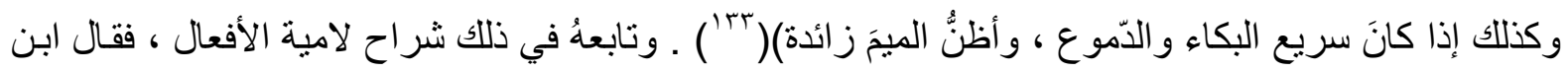

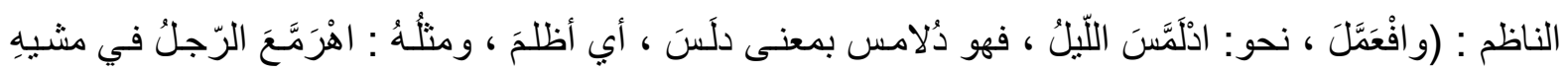

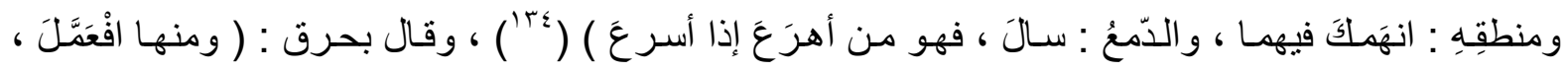

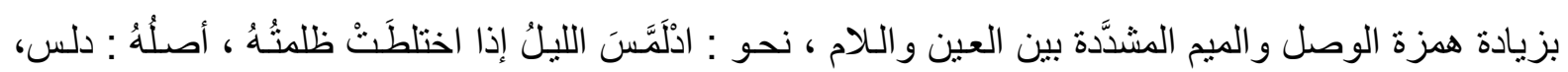

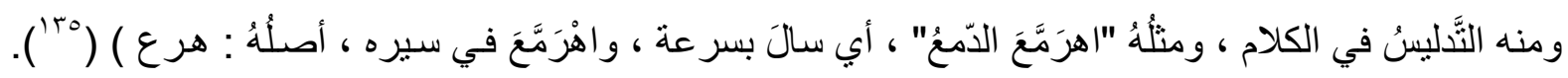

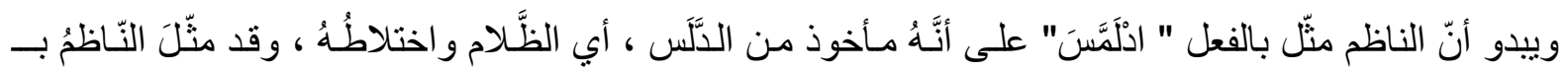

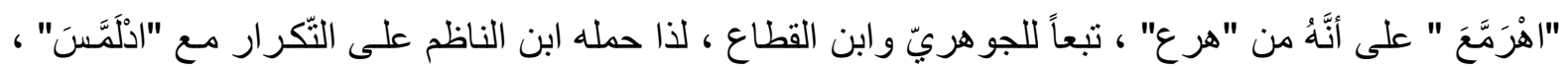




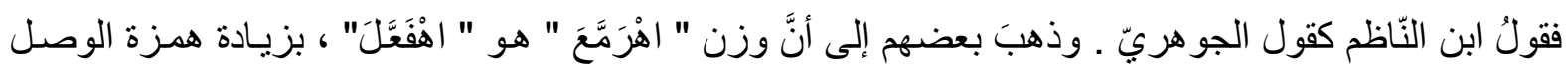

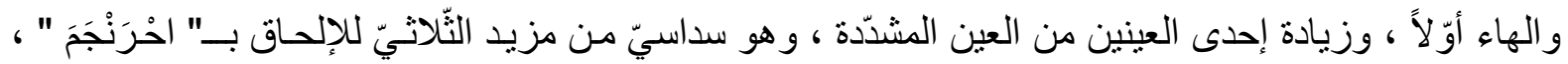

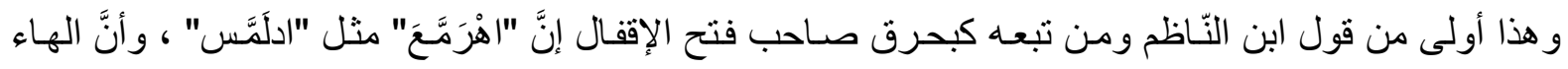

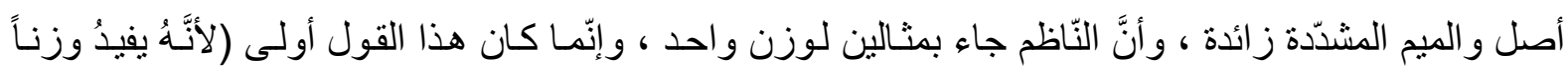

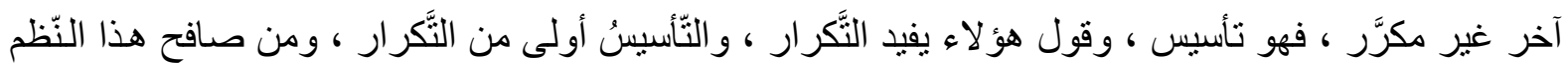

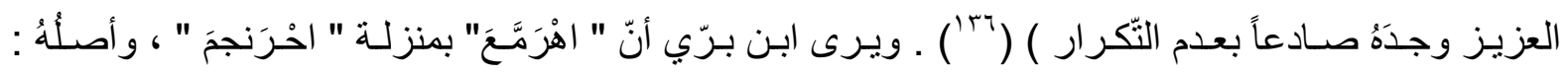

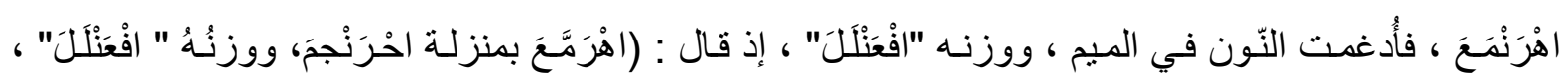

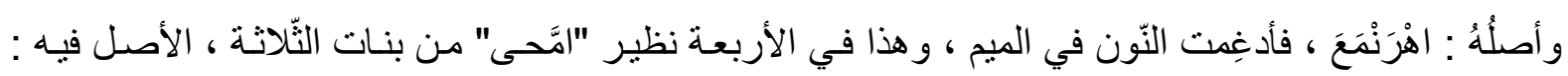

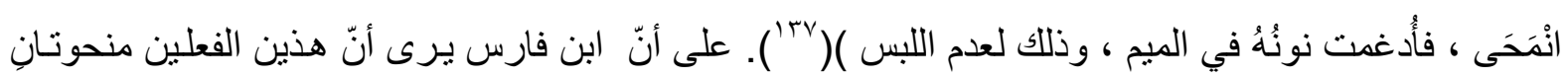

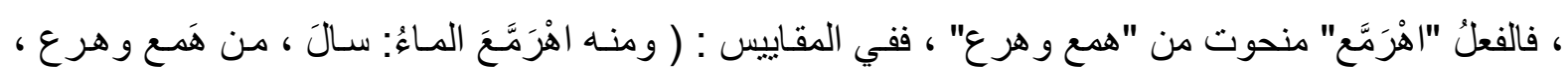

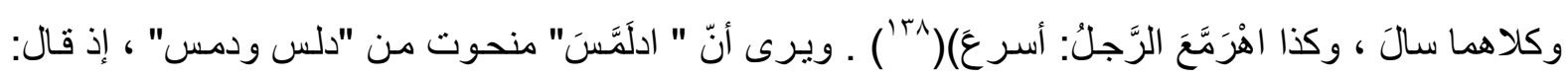

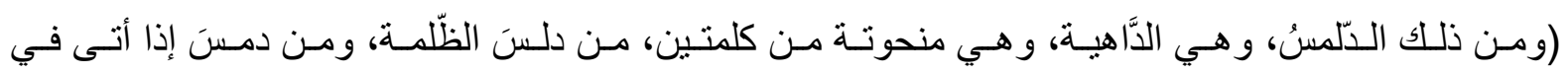

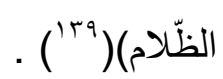

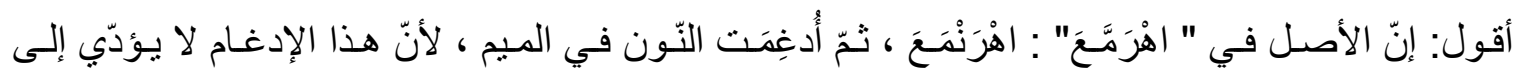

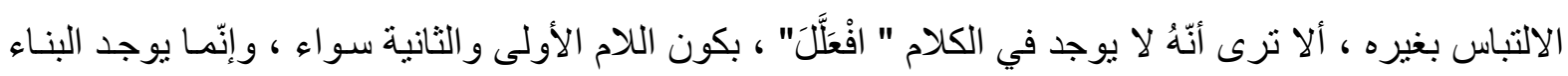

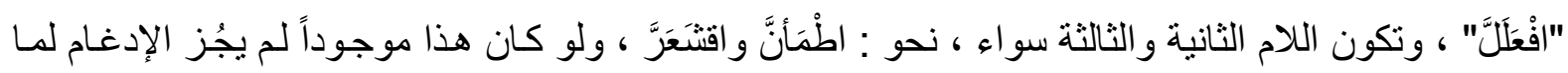

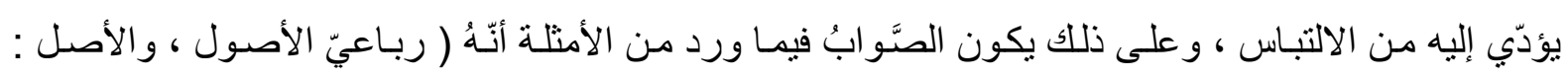

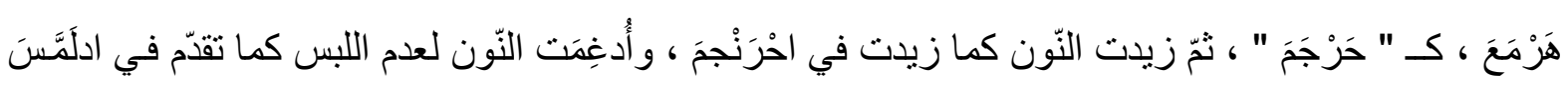

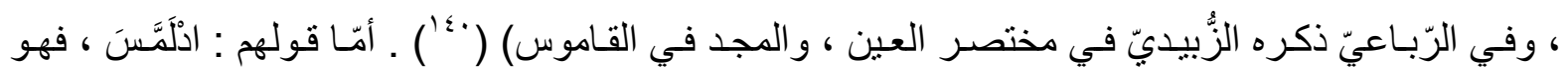

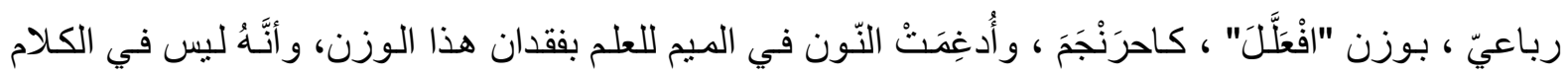

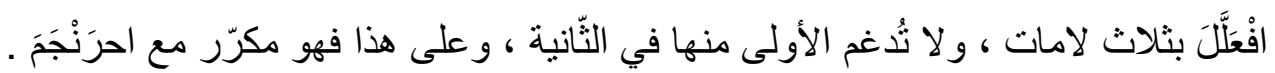

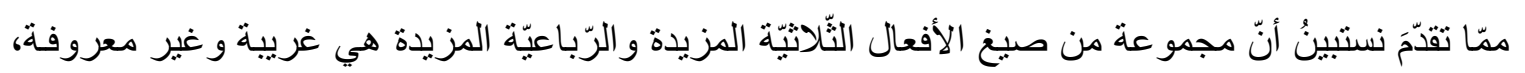

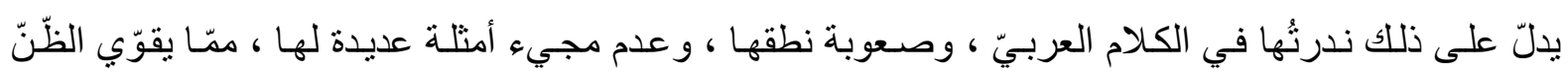

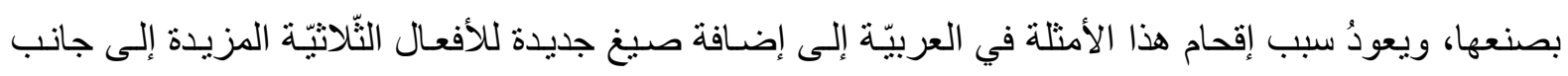

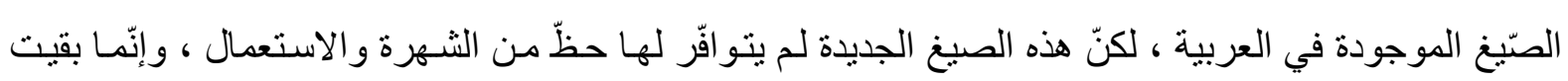

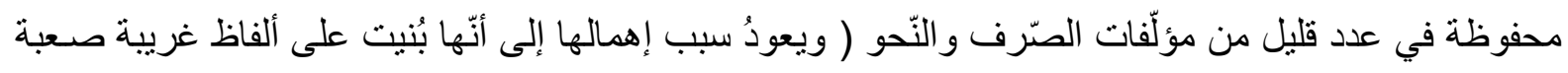

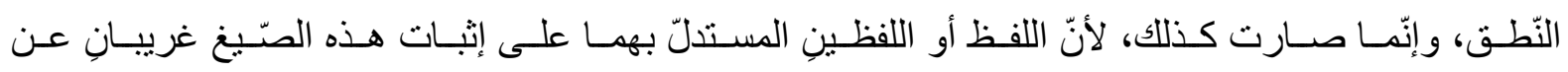

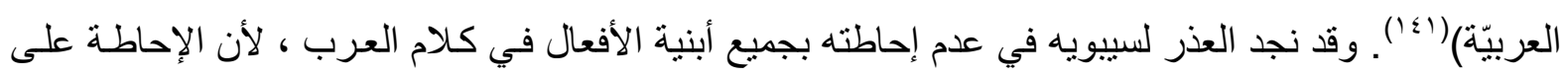

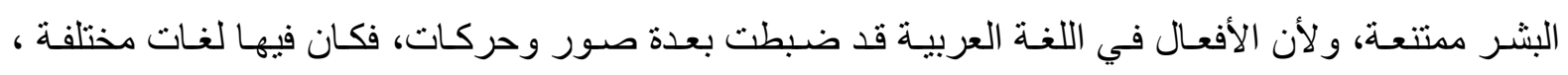

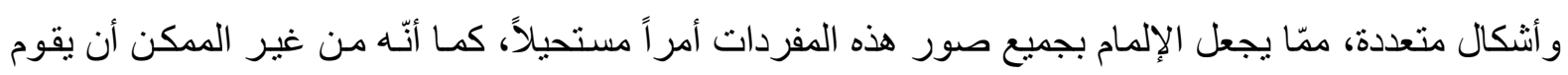


إنسان واحد بحصر كل أشكال هذه الأوزان بصورة محكمة بحيث لا يغفل منها شيئاً ، فليس من الغريب أنْ تُز ادَ على سيبويه هذه الأبنية. وإهمال سيبويه هذا العدد من الأبنيـة التي استُركت عليه يمكن تفسيره بـأمور منها : عدم وقوفه على أمثلة بعض تلك الأبنية ، و عدم وثوقهـ بمن تكلّم ببعضـها الآخر ، و وخالفته غيره في اشتقاق

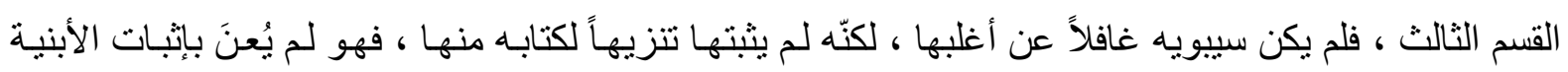
الثنَّاذة التي تخالف وجوه القو اعد العربية ، ولم يرتضِ قبول الأبنية الغريبة التي تتسب أمثلتها إلى غير الثقات ، و إنّما صبَّ جلّ اهتمامه على المشهور من الأمثلة ، و الفصيح من اللغات التي لا يشكّ أحد في صحتها ، و هذا مـا

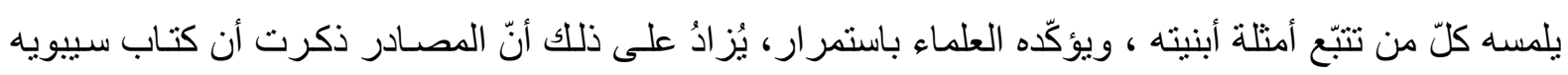
قد تعدَّدَتْ نسخُهُ، و وختلف أصحابها في ضبط بعض صور الأبنية فيه ، وقد أنثار الزُّبيدي إلى مـا أصـاب كتاب

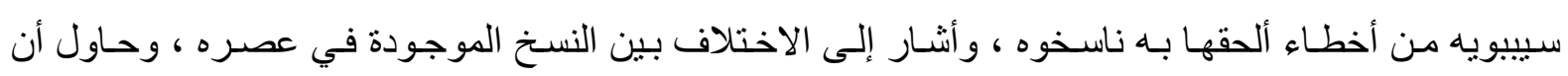

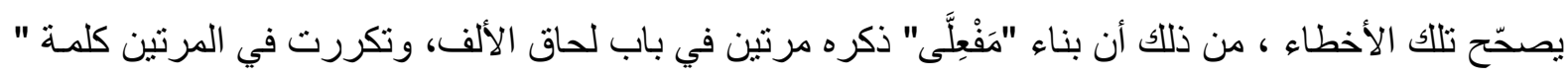

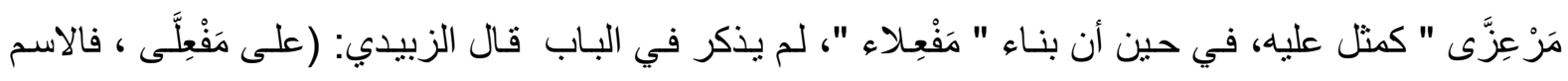

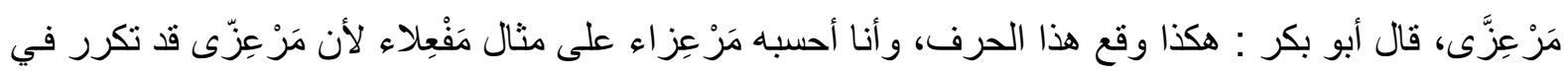

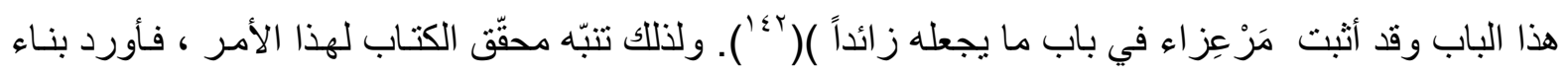

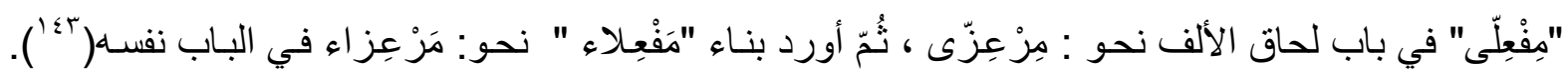
و إذا كانت الأمور كذلك فإن المجال يكونُ مفتوحاً أمام عدد من الأبنية المستدركة التي يحتمل أن يكون سييويه قد ذكر ها في كتابه ، ولكن اختلاف نستخ الكتاب، وبعض صور التحريف التي داخلت بعض الأبنية تسببا في

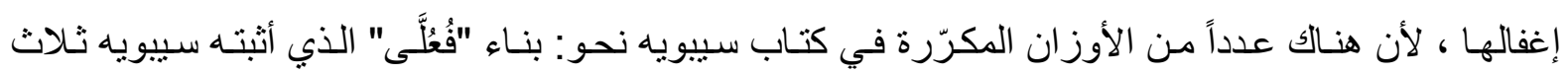

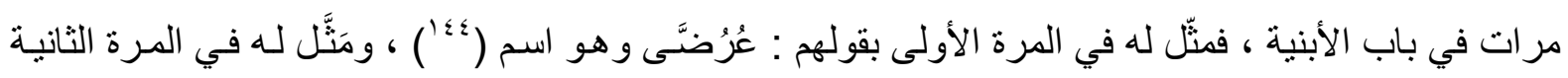

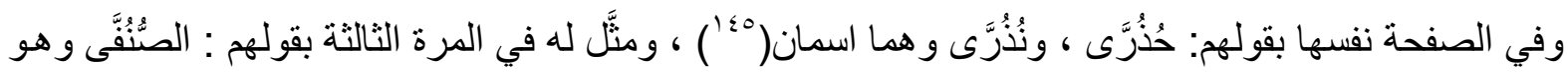

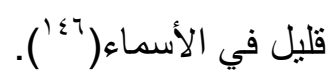

\section{هواهش البحث}

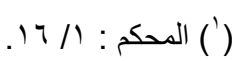

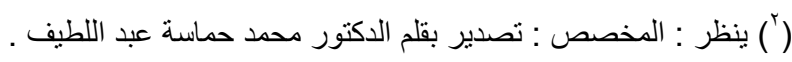

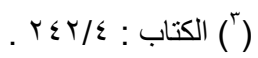

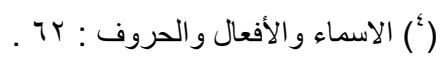

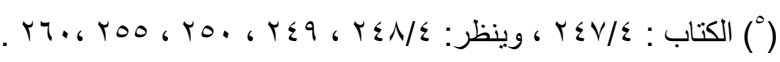

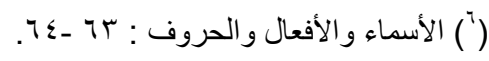

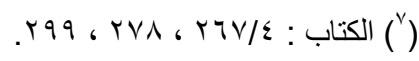

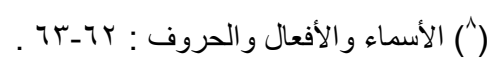

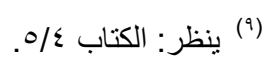

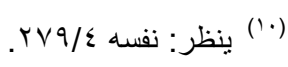

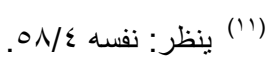

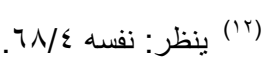




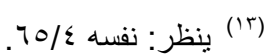

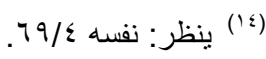

$$
\begin{aligned}
& \text { (10) }
\end{aligned}
$$

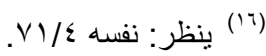

$$
\begin{aligned}
& \text { ينظر : (IV) }
\end{aligned}
$$

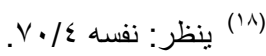

$$
\begin{aligned}
& \text { Vo/ (19) } \\
& \text {. ينظر : نفسه } \\
& \text { ينظر: (Y) } \\
& \text { ينظر : نفسه ع (r) } \\
& \text { ينظر : نفسه ع (r) } \\
& \text { ينظر : نفسه \& (r) } \\
& \text { (ro) }
\end{aligned}
$$

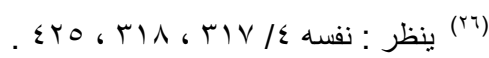

$$
\begin{aligned}
& \text { (YY) } \\
& \text { ينظر : نفسه : (Y^) } \\
& \text { Y Y ين/ (rq) }
\end{aligned}
$$

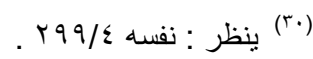

$$
\begin{aligned}
& \text { (r) } \\
& \text {. } Y \wedge V / \varepsilon: \text { : نفسه : (rr) }
\end{aligned}
$$

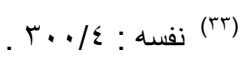

$$
\begin{aligned}
& \text { ( ) }
\end{aligned}
$$

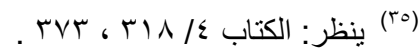

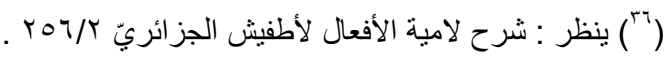

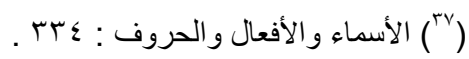

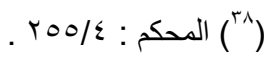

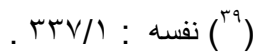

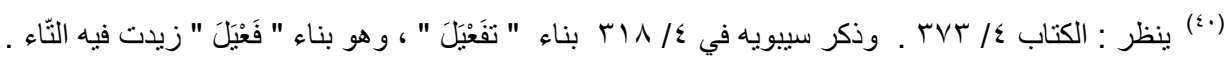

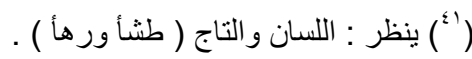

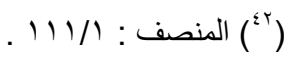

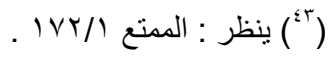

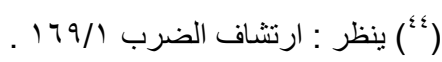

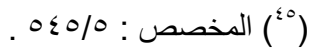

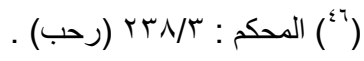

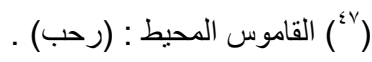

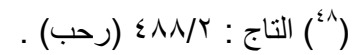

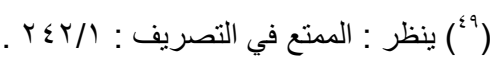

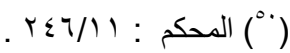

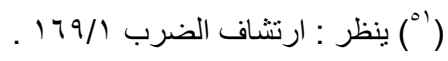




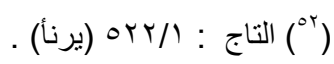

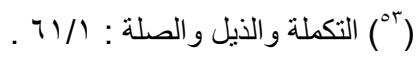

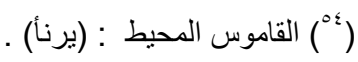

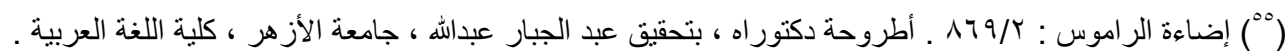

$$
\begin{aligned}
& \text { (1) }
\end{aligned}
$$

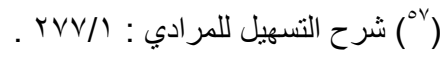

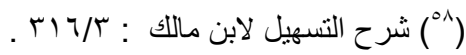

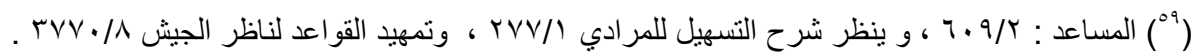

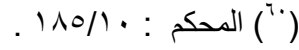

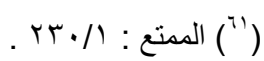

$$
\begin{aligned}
& \text { (تاج) }
\end{aligned}
$$

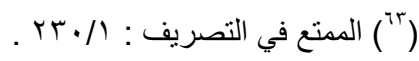

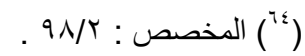

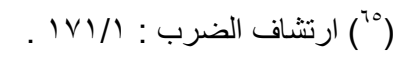

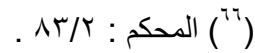

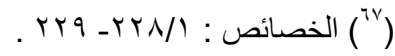

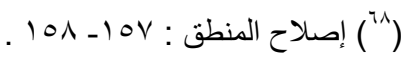

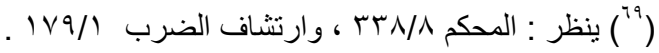

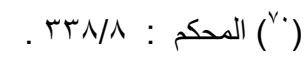

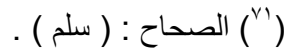

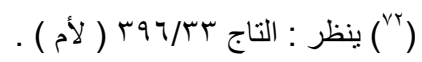

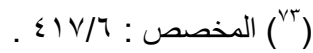

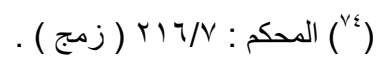

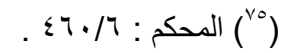

$$
\begin{aligned}
& \text { ( القاموس المحيط : ( كزز ) ) . (vi) }
\end{aligned}
$$

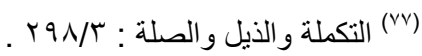

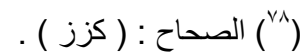

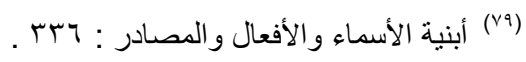

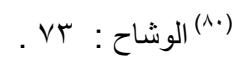

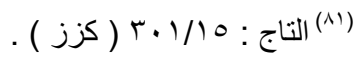

$$
\begin{aligned}
& \text { ( }
\end{aligned}
$$

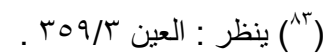

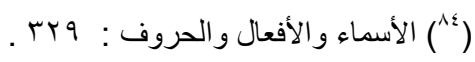

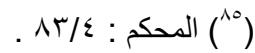

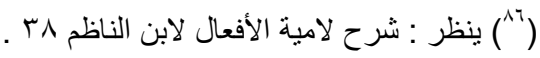

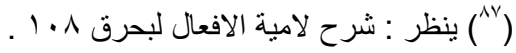

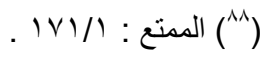

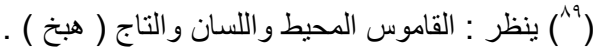

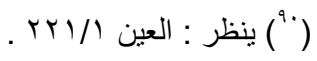




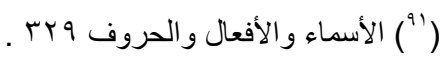

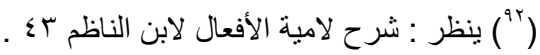

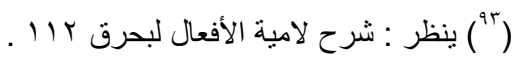

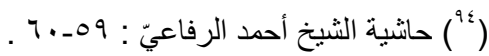

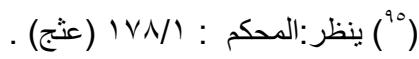

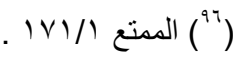

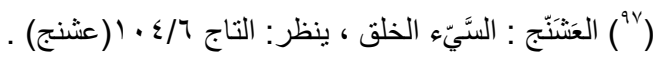

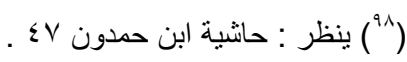

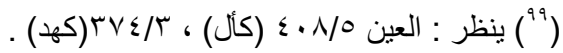

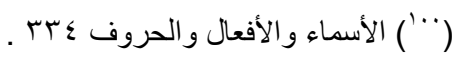

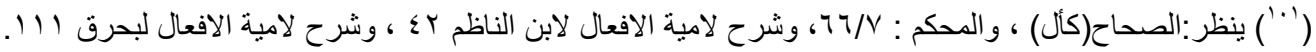

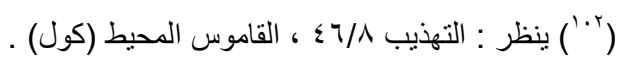

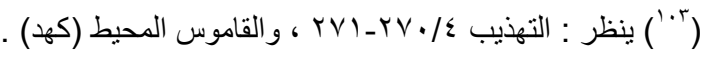

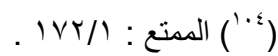

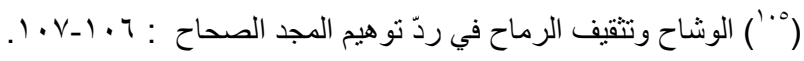

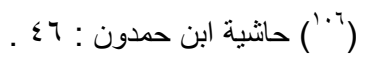

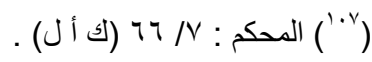

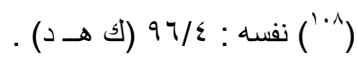

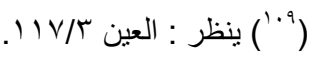

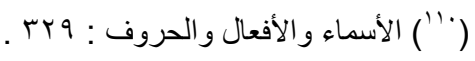

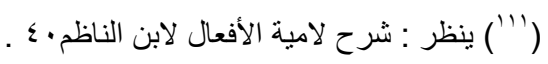

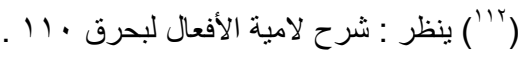

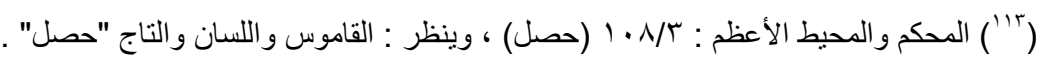

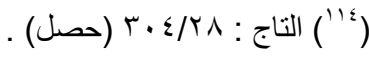

$$
\begin{aligned}
& \text { (1) }
\end{aligned}
$$

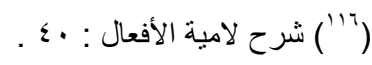

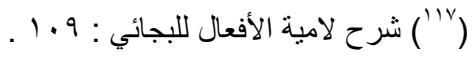

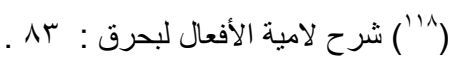

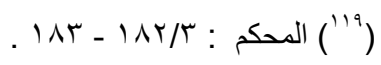

. (

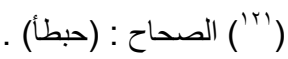

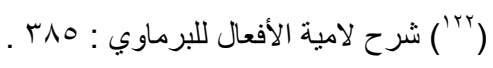

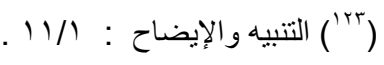

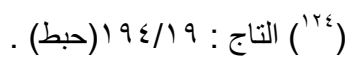

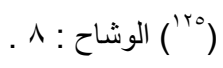

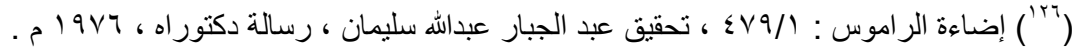

(TYY

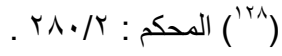

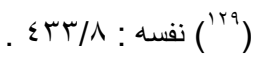




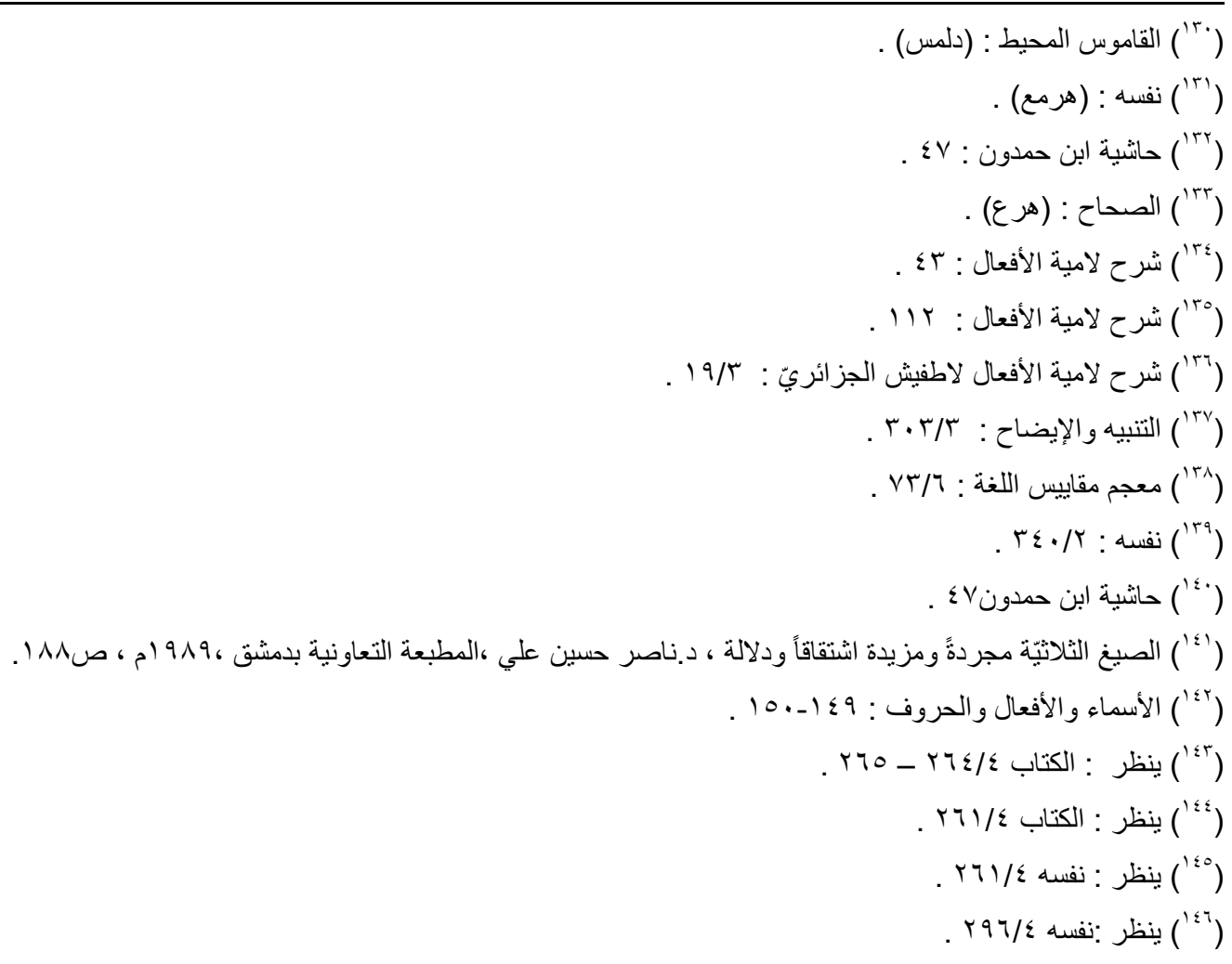

المادر والمراجع

-أبنية الأسماء و الأفعال و المصادر ، ابن القطاع (أبو القاسم علي بن جعفر بن علي السعديّ ته 10هـ) ، تحقيق د.أحمد محمد عبد الدايم ، مطبعة

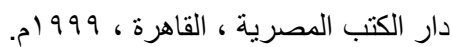

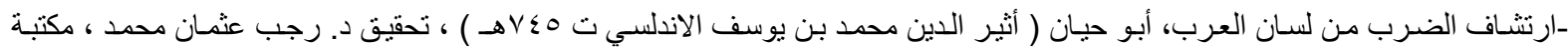

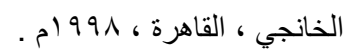
ـالأسماء و الأفعال و الحروف (أبنية سيبويه) ، الزُّبيدي ( أبو بكر محمد بن الحسن ت

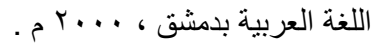

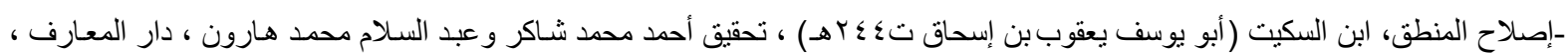
مصر ، $1919 V$

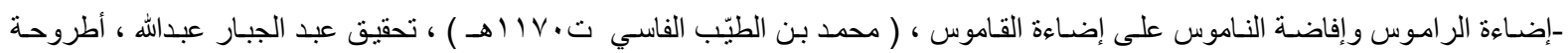

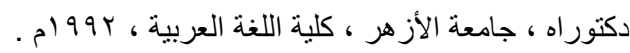

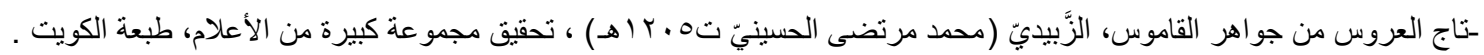

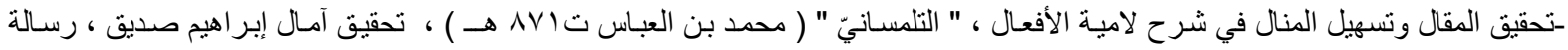

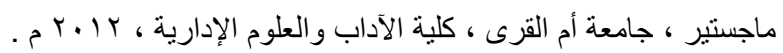
ـالتكملة و الذيل و الصلة لكتاب تاج اللغة وصحاح العربية، الصاغاني ( الحسن بن محمد ت . 70هـ ) ، تحقيق إبر اهيم إسماعيل الأبياريّ ، مطبعة

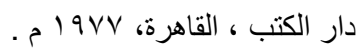

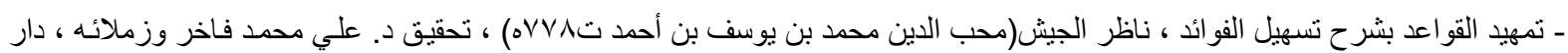

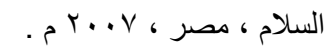

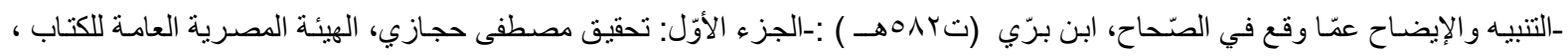

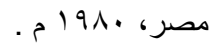

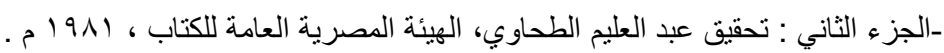

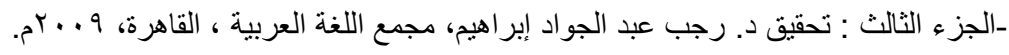


ـالجزء الر ابع : تحقيق عبد الصمد محروس ، مجمع اللغة العربية ، القاهرة ، . 1 ـ ب م . ـالجزء الخامس : تحقيق إقبال زكي سليمان ، مجمع اللغة العربية ، القاهرة ، 9 ، . . ب م .

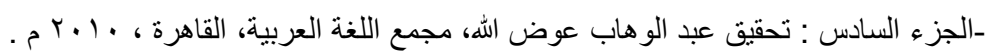

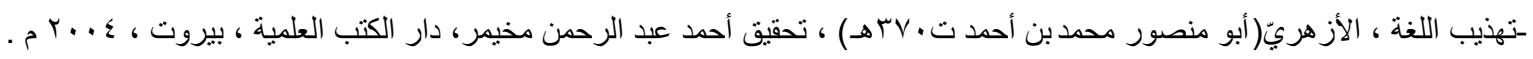

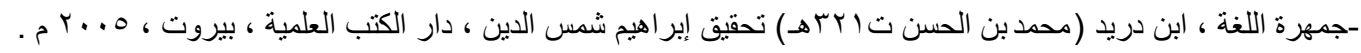

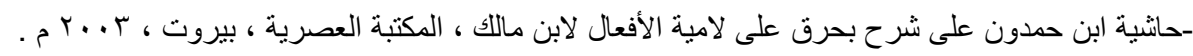

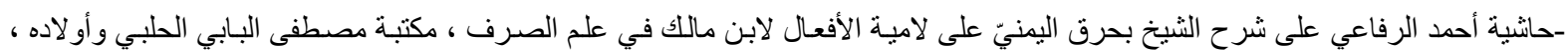

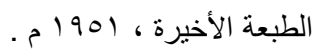

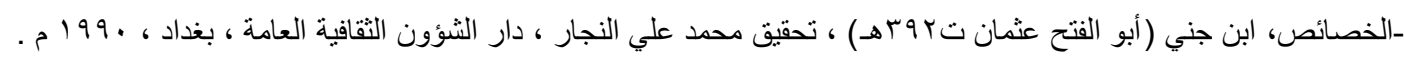

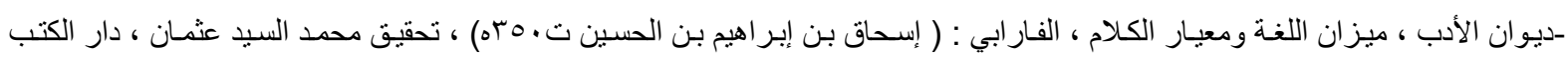

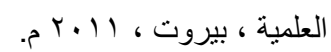

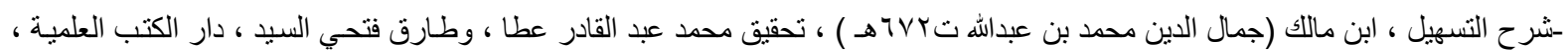

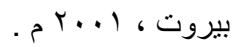

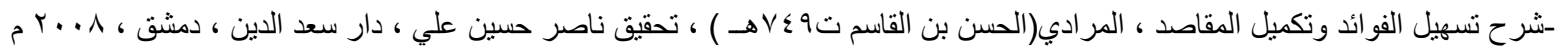

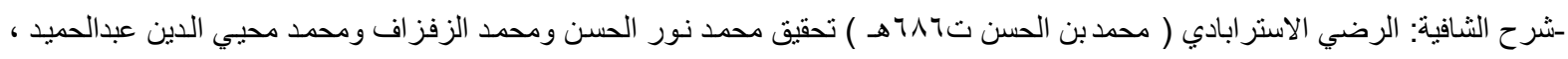

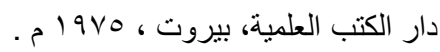

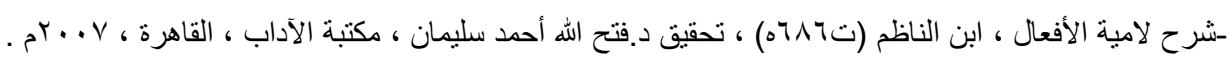

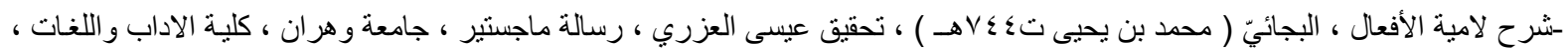

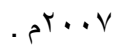

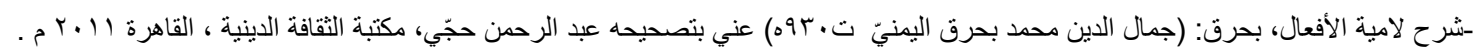

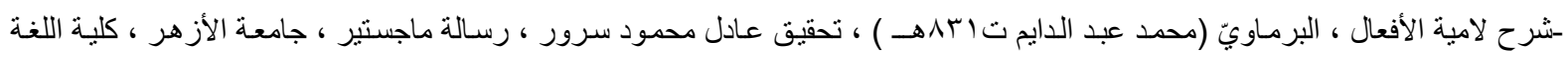

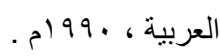

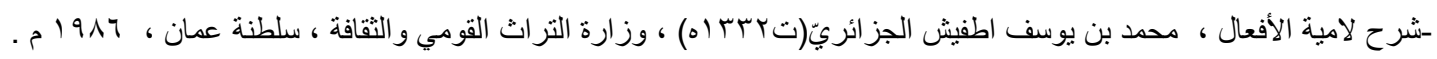

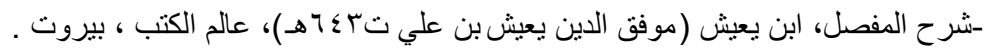
ـالصحاح، تاج اللغة وصحاح العربية، الجوهري ( أبو نصر إسماعيل بن حماد ت في حدود ل. . عـ هـ) تحقيق أحمد عبد الغفور عطار، دار الكتاب

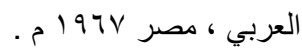
ـالصيغ الثلاثية مجردة ومزيدة اثتقاقاً ودلالة ، د. ناصر حسين علي ، المطبعة التعاونية ، دمثق ، 1919 ، م .

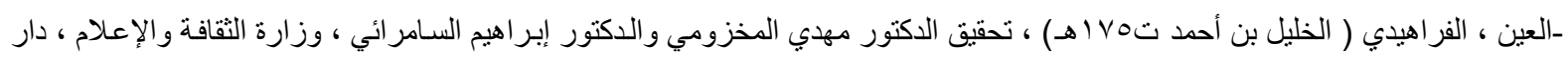

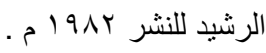

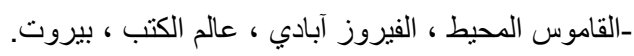

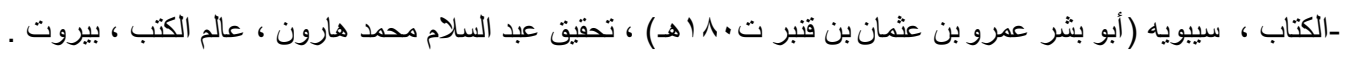

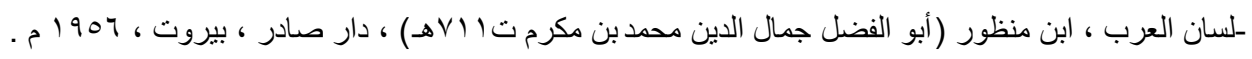

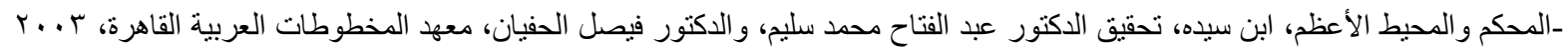

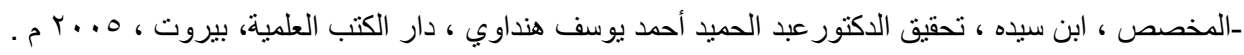

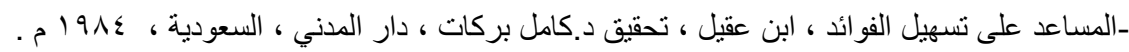

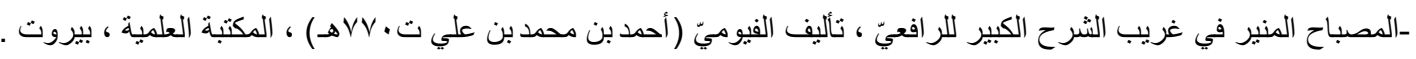

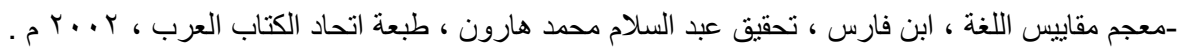

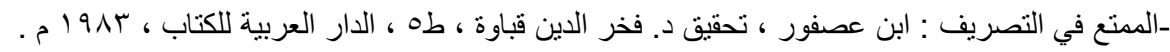

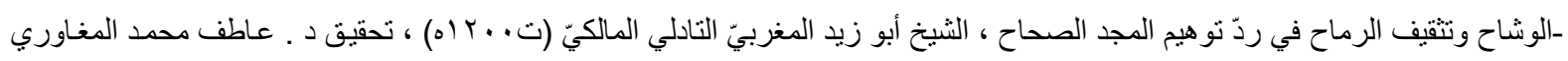

